What causes Chinese listed firms to switch bank loan provider? Evidence from a survival analysis

Jiayi Huang, Kent Matthews, Peng Zhou

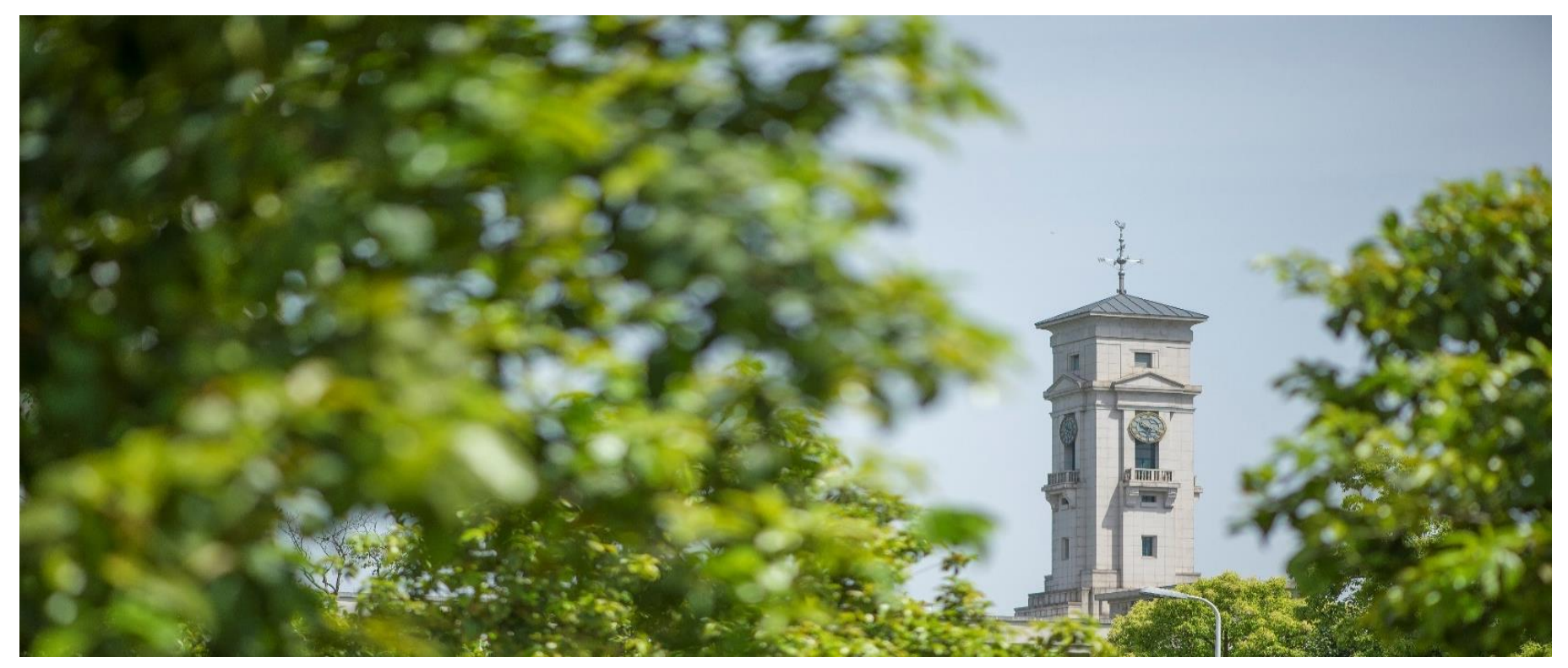


Faculty of Business, University of Nottingham Ningbo China, 199 Taikang East Road, Ningbo, 315100, Zhejiang, China.

First published 2020

This work is made available under the terms of the Creative Commons Attribution 4.0 International License:

http://creativecommons.org/licenses/by/4.0

The work is licenced to the University of Nottingham Ningbo China under the Global University Publication Licence:

https://www.nottingham.edu.cn/en/library/documents/researchsupport/global-university-publications-licence-2.0.pdf 


\title{
What Causes Chinese Listed Firms to Switch Bank Loan Provider? Evidence from A Survival Analysis ${ }^{1}$
}

\author{
Jiayi Huang ${ }^{\mathrm{a}}, *$, Kent Matthews ${ }^{\mathrm{b}, \mathrm{c}}$, Peng Zhou ${ }^{\mathrm{b}}$ \\ a School of Economics, Zhejiang Gongshang University, 18 Xuezheng Street, Hangzhou \\ 310018, China \\ b Cardiff Business School, Cardiff University, Colum Drive, Cardiff CF 10 3EU, UK \\ c Nottingham University Business School China, University of Nottingham Ningbo China, \\ 199 Taikang East Road, Ningbo 315100, China
}

October 2019

\begin{abstract}
This paper analyses the duration of firm-bank relationships and examines what drives firms in China to change from one bank loan provider to another. Matched data of firm-loan-duration to bank provides a unique panel data set of relationship between China's listed firms and their lending banks consisting of 2,102 firms listed on both the Shanghai Stock Exchange and Shenzhen Stock Exchange in the period of 1996-2016. The Cox proportional hazard model is used to allow for a semiparametric hazard function after parametrically controlling for firmspecific financial factors, industry factors, ownership characteristics, internal management changes, and external macroeconomic changes. In addition, we explore the impact of the 2008 financial crisis, bank-financial and ownership characteristics. The main finding of this study is that in an environment of growing commercialisation of relationships the firm-bank relationship between state-owned enterprises (SOEs) and state-owned banks (SOBs) in China remains super-stable. However, a change in the CEO of a firm even of a SOE increases the probability of the loan-provider being changed.
\end{abstract}

Key Terms: Firm-Bank Switch, China, Survival analysis, Hazard Function.

JEL Codes: G21, D22, G41

\section{*Corresponding Author}

\footnotetext{
${ }^{1}$ We are grateful to three anonymous referees for helpful comments. Naturally, all remaining errors are ours.
} 


\section{Introduction}

A strong firm-bank relationship is generally accepted as fundamental to smooth access to credit at favourable terms (Berger and Udell, 1995; Elsas and Krahnen, 1998). The extant theory suggests that while there is a positive impact of relationship banking on easing the credit constraints for firms, relationship banking can also create the conditions for informational capture and lock-in, resulting in unfavourable terms and conditions in loan contracts (e.g., Boot, 2000).

The rapid development of the Chinese economy has been matched by the expansion of the loan market. While the formal financial sector in China has seen a fast growth of the capital market, it remains dominated by the banking industry. According to the National Bureau of Statistics of China, 54\% of the total financing for Chinese firms were provided by banks in 2016. Historically, the banking industry was dominated by the state-owned banks (SOBs) and the economy was almost exclusively made up of state-owned enterprises (SOEs). It is commonly recognised that the SOEs were favoured over non-SOEs in access to bank credit because of government's dual dominance in banking and commerce. Political, administrative, and social connections strengthened the traditional concept of 'guanxi' in Chinese business which cemented the bank-firm relationship between SOEs and SOBs.

However, the exclusivity and strength of this relationship, and the lack of opportunity for the SOBs to diversify, have partly been the reason for their historically high non-performing loan (NPL) ratio. With the evolution of the SOEs, a rise in the private sector, and the reform of the banking industry in the 1990s, the NPL ratio of the SOEs declined gradually from $17.9 \%$ in 2003 to $1.83 \%$ in 2018 . The growth of the non-SOE sector in the Chinese economy and the decline of the SOBs in the banking sector have signalled an increasing degree of commercialisation in the firm-bank relationship ${ }^{2}$. The improvement in the performance of Chinese banks also indicate a greater focus on credit quality and repayment ability. The changing environment is arguably a challenge to the conventional firm-bank relationship, especially to the SOE-SOB relationship.

The history of the Chinese loan market may be summarised by one economic principle - switching behaviour is driven by the benefits and costs of maintaining a stable firm-bank relationship. Therefore, we are motivated to investigate if the SOE-SOB relationship - the most important firm-bank relationship in China - has evolved towards greater commercialisation. In

\footnotetext{
${ }^{2}$ More details about commercialization can be found in the Appendix A.1 Commercialization.
} 
particular, we would like to see if the interpersonal social connections (consistent with 'guanxi') between senior management in the SOEs and SOBs continues to buttress the bankfirm relationship at a time of increasing commercialisation of relationships. If this type of relationship continues undiluted then it suggests that the economic reform to restructure institutional incentives is yet to be fully aligned with the market incentives.

In China, it is well-known that firms cultivate multiple bank relationships and therefore switching from one loan provider to another does not necessarily imply a weakening of the firm-bank relationship with the previous provider. Similarly, the literature on switching of banks by firms does not necessarily imply that the firm cannot return to its previous provider at a future date. Rather than terminating a current bank relationship and switch to other banks completely, firms in China may change their bank loan providers frequently, while still maintaining a relationship with their previous banks through loan activities or other business activities. This study interrogates the literature on switching of bank loan provider by firms to develop a methodology to examine the determinants of a change in the loan provider within multiple firm-bank relationships.

A number of Chinese studies have examined the role of firm-bank relationships from a qualitative perspective, but Yin and Mathews $(2016,2017)$ have quantitatively modelled the probabilistic causes of a firm-bank switch. These studies ask the question, what is the probability of a firm switching its main credit provider given initial conditions of the firm, the conditions of the bank, and the economic environment?

This paper identifies the time-varying factors that contribute to a change. In other words, it poses the question, what are the determining factors that cause a switch? These factors could be changing conditions of the firm, changing conditions of the bank, changing conditions of the external environment, or simply a change in the CEO, which requires a repositioning of the firm-bank relationship. The answer to this research question provides insights into the commercialization of business relationships that follow from the economic reform process in China. How have firm, bank, and economic circumstances changed over time to warrant a change in firm's bank loan provider? To answer this research question, we analyse the loan duration of the listed Chinese firms and examine what drive the firms to switch from one loan provider to another.

In contrast to previous studies this paper emphasises the time-varying factors that contribute to a switch. To achieve this, we employ the semiparametric Cox proportional hazard 
model, which to the best of our knowledge is a first in the Chinese banking literature. The advantage of the semiparametric model, over the parametric probit/logit model, is that it allows for a nonparametric hazard function without imposing any functional-form restriction, while controlling for changes of those factors when a change happens in a parametric way. More importantly, a survival model such as the Cox model is designed to capture the dynamic feature of the hazard profile, i.e. the probability of a switch is time dependent. In contrast, the probit/logit model presumes either a constant probability of switch (if the duration of relationship is not included in the specification) or a linear probability of switch (if included). The semiparametric Cox model, however, does not have any parametric restriction on the hazard profile, so it is much more flexible and robust.

To pre-empt our results, we find that Chinese firms are less likely to change loan provider when the firm is large, or state-owned, or heavily leveraged. A change is more likely if the provider bank is not state-owned. These two findings underscore the continuing strength of the SOE-SOB firm-bank relationship in the face of increased competition and commercialization of the domestic credit market. This finding may not be a surprise to scholars of the Chinese banking market, but we also identify other factors that affect a change in provider. Understandably, the likelihood of a change declined during the financial crisis years of 2007-9. The likelihood of a change is sector-specific led by the real estate sector. Finally, a change in CEO in a SOE that had a lending relationship with a SOB, increased the likelihood of a change in loan provider.

Before moving on to the literature, a word is due here about Chinese banking and the concept of guanxi in the context of emerging economies. It should be noted that while guanxi is a particularly Chinese phenomenon with roots in Confucianism, the concept, which covers personal business relations and reciprocity in business is common to Asian culture (Wong, 2007; Lee et al., 2018). Like China, the banking markets of many Asian economies have dominant state-owned banking sectors that are relatively concentrated; experienced high NPL ratios, and have gone through, or are undergoing reform processes (Klapper et al., 2014). While this research examines the Chinese banking market, our findings will strike a resonance in other Asian emerging economies.

The remainder of this paper is organized as follows: Section 2 reviews the relevant theoretical foundation and empirical studies that relate to asymmetric information, and an overview of the bank-firm relationship in China. Section 3 demonstrates the methodology, the 
empirical set-up based on survival analysis, and the description of the data. Section 4 presents and discusses the estimated results and Section 5 concludes.

\section{Literature Review}

Private information plays a key role in bank-borrower relationships, and it is argued that banks accumulate private information, from closer relationships and repeated interactions with firms. Rival banks that do not have this private information may charge higher loan rates if a firm switches from its existing provider. There is broad agreement that closer relationships increase credit availability and reduce the cost of bank loans ${ }^{3}$. But it is also argued that a close firmbank relationship increases loan cost through information capture or from the presence of search costs for new loan providers resulting in rent extraction as the relationship matures ${ }^{4}$. However, the lock-in effect can be diluted through a reduction in loan size or the initiation of multiple bank relationships ${ }^{5}$. Maintaining multiple bank relationships provides liquidity insurance to firms and enables them to meet liquidity problem (Elsas et al., 2004). Moreover, Jimenez and Saurina (2004) suggest that firms borrowing from multiple banks may reduce the informational rents of the incumbent bank.

The extant literature focusses on the main factors that prompt a firm to switch lenders. Firms with an asymmetric information problem are more likely to enter into new banking relationships with different types of banks with the objective of meeting their changing needs and improve their information quality (Hadlock and James, 2002). The borrower-lender relationship is also under threat from rival lenders that may provide superior product or lower cost, therefore a borrower may terminate the relationship with the incumbent bank whenever sufficiently better loan conditions are offered by a competing bank (Petersen and Rajan, 1995; and Boot and Thakor, 2000). As firms' borrowing needs increase which cannot be met by their incumbent banks, they will switch to other banks. Firms may also switch banks due to a change in the existing relationship bank such as mergers, or restructuring (Gopalan, et al., 2011).

Turning now to the application of duration analysis in modelling switching behaviour, Ioannidou and Ongena (2010) employ a unique data set of Bolivian loans during the period of 1999 to 2003 to investigate the loan conditions and bank behaviour when firms switch to other

\footnotetext{
${ }^{3}$ For example, Berger and Udell (1995); Boot and Thakor (1994); Cole (1998); Elsas and Krahnen (1998).

${ }^{4}$ See Sharp (1990); Rajan (1992); Boot (2000); Yin et al. (2015).

${ }^{5}$ See Hubert and Schafer (2002); Agostino et al. (2012).
} 
lenders. They define the switching firm as one that is granted a new loan from a bank with which it did not have a lending relationship in the previous 12 months. Banks are categorised into two types, 'inside' and 'outside'. The former is the incumbent bank that had loan relation in the prior year, while the latter refers to the bank that did not lend to the firm in the previous year. Figure 1 illustrates the definition of a switcher, inside and outside banks. Firm A is the switcher and Bank 3 is the outside bank for firm A, because Bank 3 lent to other firms but not firm A in the prior year. Bank 1 and 2 are the switcher's inside bank as they had a lending relationship in the previous 12 months. Their study focuses on the "time for a change" and they find that the main purpose of firms switch to new banks is to obtain a lower rate on their loans, but they also find that the new bank will charge higher rates once the firm is informationally locked in by the new bank.

\section{Figure 1: Definitions of switchers, inside bank and outside banks}

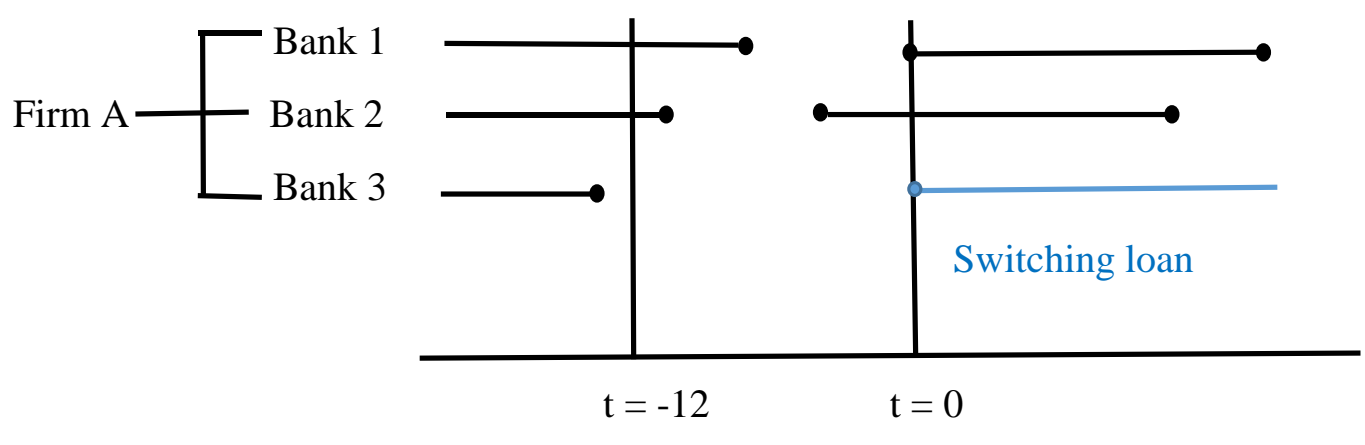

$\longleftrightarrow=$ starting and ending dates of a loan

Source: Ioannidou and Ongena (2010)

The duration of bank-firm relationship and the impact of firm-specific characteristics on the likelihood of terminating bank relationships or switching from single to multiple relationships was also studied by Ongena and Smith (2001), Farinha and Santos (2002) and Bouchellal and Castro (2016). A basic Weibull model is employed in order to find the duration dependence of these relationships, i.e. whether the likelihood of relationship ending is increasing or decreasing (or stable) over time.

Using a panel data set of the banking relationships of Norwegian firms, Ongena and Smith (2001) find that the likelihood of a firm terminating a bank relationship increased with the length of the relationship, suggesting that the benefits from relationship decays with time. Using both the parametric (Weibull and Exponential) and semi-parametric (Cox) duration model that include firm-specific variables, they show that small and young, profitable, highly 
leveraged "growth" firms, and firms that with more than one bank relationship tend to maintain shorter relationships. Apart from this, their study documents a positive duration dependence in bank relationships, which implies the likelihood of ending a bank relationship increase over time. Moreover, Farinha and Santos (2002) use a parametric duration model to model the switch from a single to a multiple bank relationship. Their results provide evidence that firms with more growth opportunities, greater leverage, less liquidity, lower profitability and delinquent bank loans are more likely to maintain shorter relationships and initial multiple relationships. Similarly, Bouchellal and Castro (2016) use a parametric continuous-time Weibull duration model to explore the determinants of a relationship closure between 1,185 firms and a major French bank. For each relationship spell they control for information on the firm-level characteristics, bank market power, pricing conditions, specific bank-firm relationship variables and the economic environment. Their findings are consistent with those of Ongena and Smith (2001) that confirms older firms, and the firms with higher turnover, default probability and profits tend to keep longer relationship with the bank. They also find that the lower the banking competition, the higher the likelihood of the bank-firm relationship terminate.

Apart from the duration analysis on bank-firm relationship duration and the choice of single or multiple banking relationships, some studies attempt to investigate the determinants of a firm's switching behaviour. According to Stephan et al. (2012)'s study, large and highly leveraged firms are more likely to switch their main bank in Ukraine. They emphasize that the power of the main bank (measured by equity holdings) is the main driver of firm switching behaviour. Additionally, they also find firms have lower performance after switching their main bank because of higher loan rates charged by the new bank. A study as to why firms switch to new banks has been conducted by Gopalan et al. (2011). Their findings suggest that transparent firms, and firms that do not have an existing relationship with large banks are more likely to form new banking relationships. Moreover, they find that firms obtain larger loan amounts when they switch and form a new banking relationship to overcome borrowing constraints. They highlight that firms may benefit from their switching behaviour with an improvement in sales growth, capital expenditure, leverage, analyst coverage, and public issuance.

A number of Chinese studies have examined the effect of bank-firm relationship on cost and availability of loans and confirm that a strong and close tie between firm and bank reduces the screening and monitoring costs of lenders and therefore reduce firms' loan costs and enhance their accessibility to bank credit. Zhou and Li (2005) use data on 83 SME firms in 
Guangdong province and document that the average duration of bank-firm relationship is 7 years and 11 years for contracts of upper bound and lower bound interest rate loans, respectively. In addition, they find a negative relation between the length of relationship and the loan cost and collateral requirement, which implies that longer duration of bank-firm relationship will reduce the cost of loans and the collateral requirement but improve the availability of loans for these firms ${ }^{6}$.

A few studies have focussed on the firm-bank relationship in the case of SMEs. Using survey data from the World Bank, He (2010) examines the bank-firm relationship and loan cost for 394 firms in 18 cities in China. They use three indicators to measure the relationship between banks and firms, which are the length of duration, the scope (or the number of bank relation) and depth of the relationship. They show that both the length and depth of the relationship influences the loan cost negatively, while the scope of the relationship positively affects the loan cost. To put it differently, SMEs that have a longer and stronger relationship with a single bank will have lower loan cost. In contrast, Wu (2005) reports a significantly positive impact on the cost of borrowing in the local market using a small sample of SMEs in Jiangsu province. Firms with a longer lender relationship duration face a higher cost of borrowing.

A recent study by He (2013) shows that SMEs with a single banking relationship face lower collateral conditions in the loan contract. Although a long and close relationship with the bank enables the SME to access bank credit more easily, these firms are more likely to suffer the "hold-up" problem that would lead to higher cost of loan for SMEs. Higher loan costs result from private information being captured by the incumbent bank. However, in a city focussed study, Yin et al. (2015) discover how relationship lending and bank competition influences the loan cost for SMEs. Their results show that firms can benefit from a less close relationship with the bank and stronger banking competition, which result in a significantly lower cost of credit for SMEs.

Much of the empirical literature on the firm-bank relationship in China focusses only on a specific geographical area or city in China, and especially the borrowing activity of SMEs. Although there is a growing literature on firm-bank relationships recently, among others, Yin and Mathews $(2016,2018)$ explicitly model the causes of firm-bank switching behaviour in China. The factors identified by these studies include initial conditions of the firm, the

\footnotetext{
${ }^{6}$ Similar findings are reported in Luo et al. (2011)
} 
conditions of the bank, and the economic environment. In addition to the existing studies, this study differs in its geographic coverage and firm size and industry. The data used covers $80 \%$ of listed firms during 1996-2016 and is more comprehensive and thus broadens the existing banking literature.

\section{Method and Data}

\subsection{Model framework}

Survival analysis (also known as duration analysis) has been commonly used in studying and modelling problems that include the duration of time before a particular occurrence, such as financial stability duration (Aka, 2006), unemployment duration (Caliendo et al., 2016) and price duration (Zhou and Dixon, 2018). Many studies have also applied survival analysis to examining the duration or termination of firm-bank relationships (Ongena and Smith, 2001; Farinha and Santos, 2002; and Bouchellal and Castro, 2016). Following their methodology, this paper employs duration models to study the passage of time before a firm changes its existing bank loan provider to another bank. Furthermore, it investigates the factors that alter the duration of the firm-bank relationship in China. The change from one bank loan provider to another can be described through a hazard function $h(t)$, which determines the rate at which a firm-bank relationship termination occurs, conditional on the relationship spell lasts at least until date $t$. The most important advantage of using a hazard function is that it provides a natural way to interpret the process that generates duration, and regression models for duration data are more easily grasped by observing how covariates affect the hazard rates. The empirical model for estimating the hazard of firms change to other lenders using the Cox proportional hazard model can be stated as:

$h(t \mid x)=h_{0}(t) \cdot \exp \left(\beta_{1} \cdot \mathbf{F}+\beta_{2} \cdot \mathbf{M}+\beta_{3} \cdot \mathbf{B}+\beta_{4} \cdot \mathbf{E}+\right.$ interactive $)$

where $h_{0}(t)$ is the baseline hazard function that captures the data dependence of duration and determines the shape of the hazard function with respect to duration of relationship. This study uses time-variant and time varying covariates and controls for firm characteristics (F), management characteristics (M), bank characteristics (B) as well as the economic environment (E), that is expected to be correlated with the hazard of the firm's behaviour regarding a change in its loan provider. In addition to this, the interactive terms are also included to examine the cross effects between ownership of firms or banks and internal or external changes. One 
significant property of the Cox model is that the baseline hazard function $h_{0}(t)$ does not influence the estimate of $\beta$, hence it is often referred as a "semiparametric" model. Instead of imposing a specific function form for $h_{0}(t)$, it is left unspecified, while covariates are still explicitly estimated. Since it is not estimating the full model, the advantage of using the Cox model is that it can avoid the biases problem caused by specifying an inappropriate baseline hazard function. Equation (1) can also be transformed into a Logit model that represents the hazard ratio:

$$
\frac{h(t \mid \mathbf{x})}{h_{0}(t)}=\exp \left(\beta_{1} \cdot \mathbf{F}+\beta_{2} \cdot \mathbf{M}+\beta_{3} \cdot \mathbf{B}+\beta_{4} \cdot \mathbf{E}+\text { interactive }\right)
$$

This study aims to identify the covariates that causes the firm to terminate a lending relationship and change to another bank within the pool of banks of the multiple relationship. For each relationship spell, this study considers variables that control for factors that affect the firm's choice to switch. This section firstly introduces the duration variables and the definition of an 'event' based on survival. Next, it describes the covariates used in this study, which can be grouped into three sets related to the firm, ownership of banks and crisis.

\subsection{Measurement of a switch}

The occurrence of switching behaviour in China is slightly different from those in the Western economies. In a Chinese characteristic economy, switching from one loan provider to another does not necessarily imply a weakening or termination of the firm-bank relationship with the previous loan provider. Hence, using the term "changing" may better reflect the actual meaning of switching under this specific context ${ }^{7}$. In this section we use the language of the 'switching' literature as applied to firm-bank relationships. The duration variable (Duration) is defined as the length (in months) a firm-bank (or loan) relationship lasts. Firms that have repeat borrowing from an incumbent bank may have a longer relationship duration, the repeat borrowing is defined as a firm re-borrows from an incumbent bank within twelve months, while re-borrowing from an existing relationship bank after twelve months or even a longer gap will be counted as a new relationship in this study. The event or failure in this study implies a change of loan-provider or switch behaviour (Switch) of the firm. Using the definition made by Ioannidou and Ongena (2010), a new loan is defined as a switch when a firm obtains a new loan from a bank with which it did not have a lending relationship during the past 12 months,

\footnotetext{
${ }^{7}$ Both the term "change" and "switch" has been used frequently in this paper, while a switch in China is clarified slightly differs from the existing literature, which captures the firm-bank relationships in a Chinese characteristic condition.
} 
while this firm may still maintain relationship with its previous lender. Following them, a switch behaviour in this study can be summarized as two types:

1) Firm $A$ borrows from the incumbent Bank $A$ in DD/MM//YY with $n$ year loan maturity, but Firm $A$ borrows from a new bank (say Bank $B$ ) during this period or after the current loan relationship ends with Bank A, then a switch occurs for Firm A.

2) Firm $A$ borrows from the incumbent Bank $A$ in DD/MM/YY with $n$ year loan maturity. After repaying the loan by the end of maturity date, there was no loan activity in the following 12 months or even a longer period, but Firm A re-borrows from Bank $A$ after 12 months or a longer gap, a switch occurs for Firm $A$ because this could be viewed as a new relationship ${ }^{89}$.

Hence, firms "move" to other banks or "add" a new bank relationship during a relationship time period or after a period that longer than 12 months is considered as a switch. Firms in China may establish new banking relationship either because they want to maintain multiple banking relationships or because they want to switch to a new bank entirely by terminating its relationships with its incumbent bank. Coding the failure variable (Switch) equal to 1 if the firm has never before borrowed from any of the banks of the current deal, as well as those re-borrowing from current bank longer than one-year gap, and 0 for repeated borrowing from current banks or termination of current bank relationship without observable new bank relationship under analyse period.

\subsection{Variable description}

To switch or not to switch, that is the question, but whose question? These could be two sides of factors, the first one is the push factor. Firms are forced to switch (or change) their bank loan provider when their financial constraint cannot be met by their incumbent bank. Similarly, a tighter credit supply and strong lock-in effect of banks can push firms to switch. For the pull factors, firms are allured to switch due to a lower switching cost, better loan conditions offered by the rival banks, and more easily to access loans from outside banks

\footnotetext{
${ }^{8}$ Our choice of 12 months can be motivated by Cole (1998), Ioannidou and Ongena (2010). In short, the value of private information diminishes over time, if a previous firm-bank relationship has been ended a long time ago (say, 12 months), it takes as much effort to collect both hard and soft-information of firm and re-established the new relationship.

${ }^{9}$ While re-borrow from the incumbent bank within 12 months will not be considered as a switch but a repeated borrowing in the data, which does not count for Type 2 switching. In general, Type 2 switching accounts for about $24 \%$ of all switching in the data, as suggested by the anonymous reviewer, we have performed additional robustness tests through excluding Type 2 switching and re-defining Type 2 switching, results have been presented in Appendix C. Additional Robustness Test.
} 
because of greater banking competition ${ }^{10}$. Apart from this, changing the economic environment such as financial crisis, a tight or loose monetary policy may cause the firm-bank relationship to change as well. Therefore, it is a three-side story within the firm, bank and environment. This study opens the "black box" by controlling for firm's management factors, a figure demonstrates the conceptual framework has been included in Appendix B.1 Conceptual Framework.

We use the existing literature as a signpost for the four sets of variables relevant to the firm's attributes that may determine its decision to terminate an existing bank relationship and switch (or change) to other banks. These variables measure firm's performance, executive information, lending bank's information and the economic environment. The variables are drawn from the literature and reviewed below. Details of variable definition can be found in Appendix A.2 Variable Descriptions. The first group of firm's specific characteristics relate to firm's size, age, growth opportunity, profitability, leverage, liquidity, ability to pledge collateral, and opacity of ownership status as well as industrial effect.

Early studies show that the age of the firm is closely linked to the duration of its relationship with a bank but its influence remains ambiguous (i.e. Petersen and Rajan, 1995, Sakai et al., 2010). In addition, large firms are assumed to be more transparent and have less dependence on bank financing which enables them to initiate a new bank relationship more easily. It is also assumed that they have higher bargaining power to negotiate with the bank for better loan conditions (Berger et al., 2005). In contrast, Diamond (1984), and Rajan (1992) state that small and young firms are more likely to be involved in the information-capture problem, and thus, bank financing is important to them. Holding the level of internal financing constant, firms with more growth opportunities should have greater external financing needs, and thus be more reliant on bank financing. Hence, the growth opportunity is measured by the sales growth and is expected to have negative impact on the likelihood of switching.

We also consider the firm's performance and risk level proxied by its profitability, leverage, and liquidity. The firm's profitability (Profit) measured by return on asset, indicates a firm's ability to generate resources and to repay its loans, which allow firms with higher profitability to improve their pricing condition. Therefore, a positive relationship between firm's profitability and its conditional hazard of switching is expected. Since bank credit is still

\footnotetext{
${ }^{10}$ See Agostino et al. (2012); Hubert and Schafer (2002); Ongena and Smith (2001); Petersen and Rajan (1995); Boot and Thakor (2000).
} 
the main source for firm financing in China, the leverage level (Leverage) indicates the firm's ability meet its long-term financial obligations. Highly leveraged firms will be more dependent on banks than firms with lower debt levels, and thus less likely to change their bank loan provider. Cash flows (Cash flows) is an indicator that identifies the liquidity risk of the firm which could affect their repayment ability, as well as future investment and borrowing. Firms that have higher cash flows are less likely to end an existing relationship so it is expected to have negative effect on the hazard of switching to other banks.

Since in general small firms are less transparent and rely heavily on bank credit in China, this study uses the ratio of the firm's tangible assets to its debt as a measure of its ability to pledge collateral (Collateral), and the ratio of intangibles assets to total assets as a measure of opaqueness (Opaqueness). Therefore, we expect that firms with less capacity to pledge collateral and lower degree of transparency are more likely to maintain the current bank relationship because it might be difficult to secure a loan from an 'outside' lender.

Other variables in this group are the classification indicators that relate to firm's heterogeneity such as ownership structure, sector dummy and size dummy. As state-owned banks still dominate the banking industry in China, it is postulated that the central and local governments can influence the loan activities of these banks in the loan market. Generally, the equity of the largest state-owned enterprises are held by state or local government agencies ${ }^{11}$. Hence, "guanxi" lending represents an important cultural component of the bank-firm relationship in China (see Yin and Matthews, 2017, and Matthews and Yin, 2019). A dummy variable $S O E$ is employed to identify whether firm ownership is state, coded 1 if the ultimate shareholders of firm include central or local government, state bureaucrats, state-owned legal entities, and 0 for those non-state-owned enterprises (i.e. private, foreign, or other ownership enterprises). A Large dummy is included to identify whether the probability of switch is higher for large sized firms or not. The classification of large and SMEs are based on the Statistical Definitions of Large, Medium-sized and Small Enterprises from the National Bureau of Statistics of China, which is described in Appendix A.2 Variable Descriptions ${ }^{12}$. To control for potential industrial effects, we aggregate the firms into eight industries according to the

\footnotetext{
${ }^{11}$ Such as State-owned Assets Supervision and Administration Commission (SASAC), the Ministry of Finance, the local Bureau of Finance, and Central Huijin Investment Ltd.

${ }^{12}$ The financial indicators calculated as ratio based on the accounting formulas when we collect these data, then we converted them into percentage in the estimation analysis to maintain consistency.
} 
Industry Classifying Index Code of listed companies released by China Securities Regulatory Commission $(\mathrm{CSRC})^{13}$.

The second group of variables relate to the characteristics of management. Faccio et al. (2016), find that female CEOs tend to avoid riskier investment and financing opportunities, also firms run by female CEOs have lower leverage, less volatile earnings, and a higher chance of survival than firms run by male CEOs. Following their study, we control for the gender of the CEO (Gender) and identify whether it would increase the hazard of making a change decision. Other management characteristics include the executive's age (CEOage) and length of tenure (Tenure).

A number of China studies have confirmed that CEO turnover has negative effects on private firms' performance ${ }^{14}$. A change of CEO can influence the strategic direction of a firm's operation and a firm's relationship with its existing loan provider. An indicator variable (Change) has been used to capture the effect of CEO change on firm's hazard of switching loan provider. A change in CEO can be expected to lower the hazard of a firm switching, because CEO turnover brings management instability and increase firm's uncertainty. Conversely, in the context of China, a new CEO brings with it established relationships forged by 'guanxi' in a previous position, thus increasing the likelihood of a change in loan provider ${ }^{15}$.

The third group of covariates relate to the characteristics of banks. Due to the nonavailability of financial data for some lending banks, particularly for those relatively small banks or banks' sub-branches in small cities or less developed area, we use the ownership of banks to characterize the impact of bank variables on the hazard of firm switching. The lending banks have been classified into six sub groups according to their ownership structure, which are five large state-owned commercial banks ( $S O B$, also known as Big5), policy banks (Policy), joint-stock commercial banks (JSCB), city commercial banks $(C C B)$, foreign banks (Foreign), other banks include rural commercial banks, urban or rural credit cooperatives, and financial institutions (Other). To emphasise the effect of bank ownership, a variable nonSOB combines all the types of lending banks except the five large SOBs.

\footnotetext{
${ }^{13}$ These are: agriculture (Agri), mining (Min), manufacturing (Manuf), construction (Constr), energy (Energy), transportation (Transp), real estate $(R E)$ and services (Serv). Eight sector dummies that takes value 1 when the firm is operating in the sector of Agriculture /Mining /Manufacturing /Construction /Energy /Transportation/Real estate /Service, 0 otherwise.

${ }^{14}$ For example, Yu and Xu (2016); and Yin (2017)

${ }^{15}$ Where CEO data is not available we use information on the Chairman.
} 
Lastly, the fourth set of covariates relate to the macro-economic environment, which include monetary policy instrument and crisis dummy variables. China's monetary policy has frequently changed in recent years. To guide liquidity levels, the People's Bank of China $(\mathrm{PBoC})$ implement adjustments in its monetary framework to pave the way for establishing a short-term PBoC policy rate like that used in advanced economies. The PBoC frequently adjusts reserve requirements and the benchmark deposit and lending rates to stabilize economic fluctuations. Three instruments which including two price-based (Lending rate and Reserve) and an informal quantitative-based (Guidance) monetary tools have been employed to measure the effect of changing the stance of monetary policy on firm's switch behaviour. Because this study focuses on lending and borrowing relationships, the interest rate is denoted by the RMB one-year benchmark lending rate rather than RMB 1-year benchmark deposit rate. The reserve requirement denoted by the reserve ratio for large and small financial institution. In addition, following Chen et al. (2017), five dummy variables have been used to proxy five stances of non-standard monetary policy tool window guidance, definition of each stance has been shown in Appendix A.2 Variable Descriptions.

On the other side, in response to the financial crisis during 2007-2008, the central government launched a stimulus package of 4 trillion yuan that included policies to loosen control on banks so they can expand credit in late 2008. The stimulus plan was mainly targeted in key areas such as rural infrastructure and transportation that are dominated by SOEs that can be traced to state control over its banking system and corporate sector. It is found that the effectiveness of China's stimulus plan stems from the contribution of the SOEs (Wen and Wu, 2014). During the recession period, SOEs expanded their borrowing, investment and production capacity and generated a rapid recovery of aggregate demand with credit provided by the SOBs. This study includes a crisis dummy (Crisis) as well as several interactive terms that capture the cross effects between crisis dummy and ownerships of firms or banks, also the cross effects between CEO turnover and ownership of firms or banks.

\subsection{Sample selection and data source}

The data used in this study is mainly accessed from the China Stock Market and Accounting Research (CSMAR) database of Shenzhen GTA Data Technology Co., Ltd. GTA CSMAR is a unique, comprehensive database of China stock returns, covering all companies listed on the Shanghai Stock Exchange and the Shenzhen Stock Exchange and provides the most accurate, reliable and useful financial data that includes the data on China stock markets, 
bank loan, financial statements and corporate governance. We use the data of listed companies which include state and non-state-owned companies ${ }^{16}$. Due to the complex ownership policy, structure and penetration of the state, SOEs are often less isolated from the legal framework applicable to other companies. It is also argued that SOEs focus more on social outcomes and aim at non-commercial goals rather than maximization of firm value or profit. To avoid this bias, we use the data of A-Share companies listed on the Shanghai and Shenzhen stock exchanges from 1996-2016 ${ }^{17}$. An advantage of using listed firms is that they have to provide a high degree of transparency and disclosure of information due to the legal structure of stock exchanges, which ensures their financial data more reliable than that of non-listed SOEs.

We collect data on four categories from China Listed Firms Research Series data: Bank loan, Financial Statements, Corporate Governance and Equity Nature. The loan data describes the relationship between borrower (firm) and bank is annually collected from Bank Loan category that includes the name of the lending bank, loan duration, borrowing amount, starting and ending date of loan relation. In addition, the data of firm-specific variables is collected from Balance Sheet Statement, Income Statement and Statement of Cash Flows from the Financial Statement categories. As regards the industry and ownership classification indicator, the data is collected from the Sector and Equity Nature categories ${ }^{18}$. Moreover, the data of CEO's characteristics is collected from the Executive information from the Corporate Governance category ${ }^{19}$. As regards the monetary policy instruments, the 1-year benchmark lending rate and reserve requirement ratios can be accessed from the website of People's Bank of China (PBoC), the step-by-step development of PBoC's non-standard window guidance policy can be found from the quarterly China Monetary Policy Report and the indicators of five guidance stances can be referred from the definitions made by Chen et al. (2017).

\footnotetext{
${ }^{16}$ The advantage of using listed data is that they meet audit and accounting standards specified by the China Securities Regulatory Commission and therefore meet minimum audit transparency conditions. Hence there is little differentiation in audit quality and does not require an independent cross-validation of the loan book as in Khwaja and Mian (2005).

${ }^{17}$ In order to be a publicly listed company, a SOE must be restructured into a stock company through the sale of shares to other companies, legal entities or its employees firstly. Next, the SOE sells a part of shares (usually $1 / 3$ ) to the general public. Hence, shares of SOE have been split into two parts: non-tradable shares of state or stateowned legal entity, and tradable shares of individual investors or private enterprises. Once firms become publicly listed, they have to focus on the interest of shareholders.

${ }^{18}$ The data may include involuntary switches due to a breach of the loan covenant. While we cannot identify these firms directly, any involuntary switch would be correlated with firm-specific variables in the model. We are grateful to an anonymous referee for pointing this out.

${ }^{19}$ Apart from using the CSMAR database, the 20-year data of GDP deflator and exchange are collected from the Word Bank.
} 


\subsection{Descriptive statistics}

By organizing the duration data in spells, where a spell describes the number of months of a firm-bank relationship, it can be seen in Figure 2, that the mean duration of these bankfirm relationships is 27.38 months, but they last longer in the group of large firms (about 28.33 months) than in the small and medium firms (around 25.33 months, on average). In addition, these relationships last on average 30.97 months in the group of state-owned firms, which is relatively longer than non-state-owned firms that is 23.55 months. The survival analysis shows that $75 \%$ of these firm-bank relationships survive up to 13 months, $50 \%$ of these relationships survives up to 36 months, but only $25 \%$ of these relationships survive longer than 99 months. A benchmark model will be estimated by including all sets of covariates as well as interactive terms. Due to the fact that SOEs access to preferential lending while small firms are less easily to obtain funds relative to other firms, separate regressions for different groups will be considered in this study, which includes subsamples of SOEs, non-SOEs, large, and medium and small firms (SMEs). Furthermore, robustness test will be performed by adding the number of bank relationships (Number) and geographical effects, and separate regressions that without or with the additional variables.

Figure 2: Mean duration among different sizes or ownership of firms

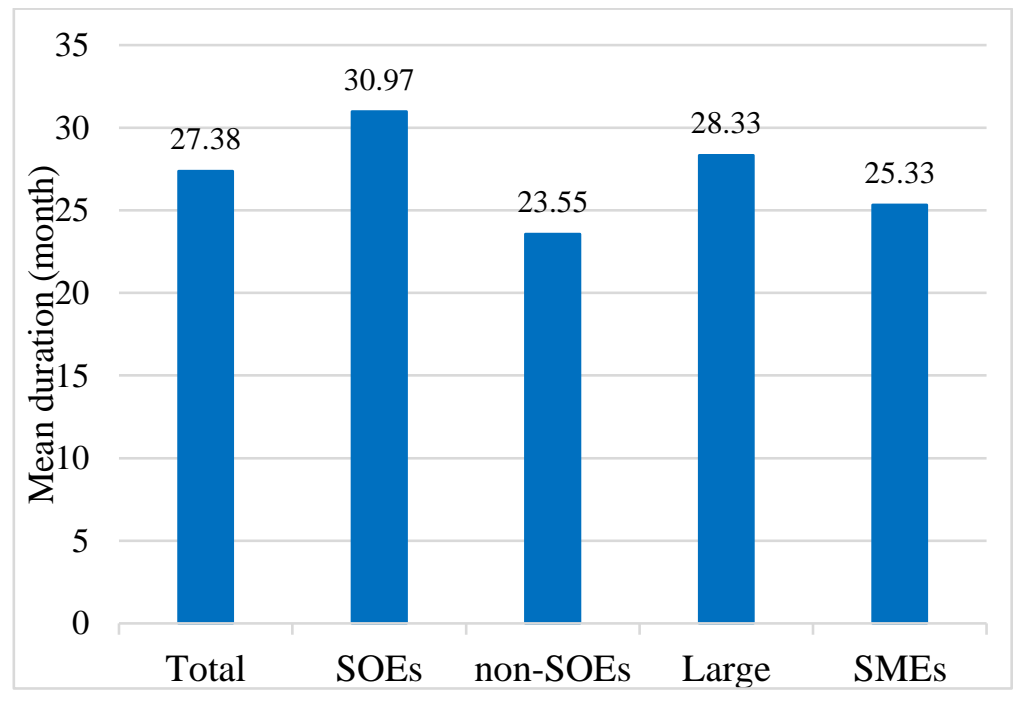

Table 1 presents summary statistics on duration, lending, and firm-characteristic variables. With respect to the characteristics of executives, $95 \%$ of the sample of firms are running by male CEOs and the average duration of a CEO's tenure is 3 years. Most firms retain multiple bank relationships during the sample period, $48.16 \%$ of the listed firms changed their lender after their previous borrowing. The main reason for the high incidence of multiple bank 
relationships is that this study counts each borrowing-lending relationship as one observation, a firm with multiple borrowing relationships enters as two or more observations. More details of matched firm (loan)-bank relationship dataset, censoring issue and descriptive statistics are set out in Appendix A.3 Descriptive Analysis.

Table 1: Descriptive summary

\begin{tabular}{llllll}
\hline Variable & Obs. & Mean & Std. Dev. & Min & Max \\
\hline Duration (month) & 7,570 & 27.378 & 26.232 & 0.033 & 240.132 \\
Loan (CNY mil) & 7,570 & 198.000 & 663.000 & 0.088 & $32,400.000$ \\
Age (month) & 7,570 & 172.158 & 64.366 & 24.592 & 398.466 \\
Size & 7,570 & 22.125 & 1.079 & 18.542 & 27.006 \\
SOE & 7,570 & 0.416 & 0.493 & 0.000 & 1.000 \\
Profit (\%) & 7,570 & 2.780 & 4.939 & -48.316 & 49.637 \\
Leverage (\%) & 7,570 & 6.833 & 9.276 & 0.000 & 77.506 \\
Cash flows $(\%)$ & 7,570 & 9.554 & 8.595 & 0.000 & 79.765 \\
Growth (\%) & 7,570 & 0.742 & 19.623 & -0.984 & 1497.156 \\
Collateral $(\%)$ & 7,570 & 1681.894 & 17785.480 & 76.667 & 1265251 \\
Opaqueness $(\%)$ & 7,570 & 5.052 & 6.944 & 0.000 & 81.532 \\
CEO age(year) & 7,570 & 48.205 & 6.301 & 28.000 & 71.000 \\
Gender & 7,570 & 0.945 & 0.229 & 0.000 & 1.000 \\
Tenure(month) & 7,570 & 40.801 & 36.818 & 6.000 & 216.000 \\
Change & 7,570 & 0.126 & 0.332 & 0.000 & 1.000 \\
Big5 & 7,570 & 0.275 & 0.447 & 0.000 & 1.000 \\
JSCBs & 7,570 & 0.419 & 0.493 & 0.000 & 1.000 \\
CCBs & 7,570 & 0.144 & 0.351 & 0.000 & 1.000 \\
Lending rate $(\%)$ & 7,570 & 5.917 & 0.533 & 4.967 & 7.164 \\
Reserve rate (\%) & 7,570 & 17.098 & 2.726 & 6.285 & 19.347 \\
Crisis & 7,570 & 0.110 & 0.313 & 0.000 & 1.000 \\
Number & 7,570 & 4.806 & 3.944 & 1.000 & 28.000 \\
\hline
\end{tabular}

\section{Empirical Results}

\subsection{Survival analysis}

We now turn to the empirical results. Estimation is conducted in a series of stages. Without making assumptions about the functional form of survival and cumulative hazard function, and the effects of covariates, we obtain the plots of the Kaplan-Meier survival estimate and Nelson-Aalen cumulated hazard estimate (not shown) for the overall sample of listed firms, state and non-state groups, large, medium and small groups. From these results we can confirm that state-owned firms and large firms' bank relationships have a better survival 
experience than non-state-owned firms and medium and small-sized firms. The hazard of changing to new lender is correspondently higher for non-state-owned firms and SMEs. The term baseline generally means that these are the functions when all covariates are set to zero, a baseline hazard contribution is defined at every analytical time $t$ at which a change in bank loan provider or switch (or failure) occurs and is undefined at other times. After obtaining the baseline hazard contributions, a smoothing operation is performed. Under a Cox model, all change (switch) times contribute to the estimate of the baseline hazard, not just those of which $\mathrm{SOE}=1$, and the baseline hazard may in turn be converted to be the hazard for any covariate pattern using a proportionality assumption. Generally, the probability of SOEs changing their loan provider (switch) is relatively lower than non-SOEs.

Using the Cox proportional hazard model to estimate the effect of the firm-specific characteristics and other covariates on the conditional probability of a switch to other lenders, the estimation results are reported in Table 2. Instead of reporting the hazard ratios generated from the survival analysis, we report the estimated coefficients because it gives the immediate direction of covariate effects. Exponential coefficients can be interpreted as the ratio of the hazards for one-unit change in the corresponding covariate. There are two ways to interpret the signs on the coefficient estimates represented by $\beta$ in the empirical model. First, each coefficient estimate indicates the partial impact of a covariate on the hazard of firm changes its lender, holding duration constant. Second, due to the hazard rate being inversely related to the duration, a positive (negative) coefficient estimate implies a shorter (longer) firm-bank relationship duration.

Column (1) shows the results for the benchmark model which including all sets of covariates. The results from the benchmark model demonstrate that only the coefficients on Age, Size, SOE, Leverage, Tenure, Change, SOBs, CCBs, Lending rate, Reserve and Crisis are statistically significant. From the signs of the estimated coefficients, we can infer that, young and small firms, firms with a longer CEO tenure, and also firms that experience a new CEO are more likely to change bank loan provider (switch). However, by controlling for the ownership and size of firms, the results indicate that both SOEs firms and larges firms are less likely to switch but tend to keep stronger and longer lasting relationships with the banks, which proves that the observed difference in the mean duration of firm-bank relationships between state and non-state firms, and also between large, medium and small firms observed in the descriptive statistics, is statistically significant. The coefficients of SOE show that the hazard of switching 
loan provider is $9.79 \%$ lower if it is a state-owned firms ${ }^{20}$, this effect is stronger for subsample of large firms.

Additionally, the conditional likelihood of a change (switch) is significantly lower for firms with a higher level of leverage and, it seems that those less risky firms benefit from better loan conditions than smaller and less profitable firms, and therefore suffer less from the information monopoly of the banks. This could also be the result of mutual interest of these firms and the banks to maintain their relationships. However, the cash flows becomes insignificant when additional sets of regressors are added in the benchmark model (see Colum (3), (5) and (7) in the robustness test result Table 3 for significant coefficient). Similarly, the proxies for the firm's profitability, growth opportunity, ability of collateral, and opacity, are not significant although correctly signed.

Regarding the managerial characteristics of firms, it is seen that while there is a positive and significant impact of CEO's tenure on the hazard of switching, the quantitative effect is very small, a 1-year increase in CEO's tenure increase the hazard of switching by only $0.1 \%$ and therefore can be considered as statistically significant but economically insignificant. However, a CEO change implies that the firm that experiences a change in the CEO during a current bank relationship has an increased hazard of changing loan provider. An arriving CEO may bring with it the baggage of previous relationships with banks developed in their previous position. It is likely that firms that have a new CEO, especially those with political connections, are more able to use their connections to access better credit conditions, increasing the probability of a switch ${ }^{21}$. The insignificant coefficients of age and gender of firm's CEO show no evidence that firms run by male CEOs have higher probability of changing their loan provider than firms run by female CEOs in China.

When ownership of the bank is considered, the coefficients on the $S O B$ and $C C B$ are statistically significant, with negative and positive sign, respectively. It is easy to understand that firms borrowing from the five large SOBs (also called Big5) are more likely to maintain

\footnotetext{
${ }^{20}$ Given the Cox proportional hazard function $h(t)=h_{0}(t) \exp \left(\boldsymbol{\beta}^{\prime} \mathbf{x}\right)$, then hazard ratio $\frac{h(t \mid \mathrm{X})}{h_{0}(t)}=\exp (\beta \operatorname{SOE})$. For example, if the exponential coefficients generates the hazard ratio $<1$ means that 1 unit change of a particular covariate would lower the hazard of switching by (1-hazard ratio)*100 percent, while if the hazard ratio $>1$ means the covariate would increase the hazard of switching by (hazard ratio-1)*100 percent. The signs of the estimated coefficients directly indicate a positive or negative effect of particular covariate on the hazard of switching loan provider.

${ }^{21}$ The political connection route is well documented in the literature (Khwaja and Mian 2005, Charumilind et al. 2006; Claessens et al. 2008; Yu and Pan 2008; Houston et al. 2014; Yang et al. 2018). However, the CEO's political connection link has not been explicitly modelled in this paper and left for future investigation.
} 
long and stable relationships. The hazard of changing loan provider for borrowers of SOBs is $32.83 \%$ lower than those firms that do not borrow from SOBs, and this effect is stronger for the subsample of non-SOEs. The implication is that having bank relationships with the five large SOBs make these non-SOEs less likely to change their credit. However, firms that borrow from city commercial banks (CCBs) have a hazard of switching $16.88 \%$ higher than firms that do not borrow from CCBs. The reason for a switch not only depends on firms, but also on banks. From the bank's perspective, CCBs may not be willing to continue with the loanrelationship. This may be due to several possibilities. A firm's performance may have deteriorated during the lending relationship period, which may give a negative signal to the incumbent bank, resulting in an unsuccessful loan renewal. Alternatively, the bank may react strategically and build up stable relationships with particular types of firms or particular sectors.

Turning to the external effect of the economic environment, the results show that changes in PBoC's benchmark lending rate and reserve ratio have a significant impact on the hazard of changing a loan provider. The higher the lending rate or reserve ratio, the higher the likelihood of firm's changing their loan provider, in particular this macro impacts are more significant for non-SOEs' switch behaviour. Moreover, the influence of changing lending rate on firms switch probability is greater than changing the reserve requirements, which is $8.33 \%$ and $1.61 \%$ respectively. Nevertheless, the results from survival analysis shows that there is no significant impact of informal window guidance on firm's switch behaviour or duration of firmbank relationship. Moreover, we note we find that the crisis dummy variable has a negatively significant effect on a firm's probability to switch for all types of firms (see Colum (1)-(6)). Not surprisingly firms are less likely to switch during the financial crisis period between 2007 and 2009. One surprising finding is that the interaction terms shows that if there is CEO turnover and firm's lending banks are large SOBs, the likelihood of switching tends to be higher, and this effect is particularly significant in state-owned firms group. This higher switch probability could possibly be the case of a SOE-SOBs relationship changing to another large SOB through the political connection or cultural "guanxi" route.

Column (2) shows the variable 'nonSOB' to control for ownership which covers policy banks (PB), joint-stock commercial banks (JSCB), city commercial banks (CCB), foreign banks (FB) and other types of lending banks (Other) ${ }^{22}$. A positive and significant coefficient of nonSOB confirms that if a firm's existing lending bank is a non-SOB, they are more likely to

\footnotetext{
${ }^{22}$ We combine all types of lending banks as non-SOBs except for the five large SOBs (or Big5).
} 
change loan provider banks. In addition, Columns (3) to (6) present the results for the groups of SOEs, non-SOEs, 'large', 'medium and SMEs', respectively. Some differences are observed. It can be seen that the age of the firm is only significant in the subsample of large firms. In other words, older large firms are less likely to switch compared to medium and small firms. This lower hazard of changing provider (switching) is not found in state or non-state groups, because the age of firms does not significant in terms of ownership, but it does matters in terms of size. Consistent with the benchmark result, the higher a firms' leverage and previous borrowing from the SOBs, the lower the hazard of changing loan provider for the four groups of enterprise, and they were all less likely to switch during the crisis period.

While changing in CEO and borrowing from CCBs increases the likelihood of a change in loan provider (switch) for these groups, this effect is not significant for SMEs. In addition, the coefficient on the SOE dummy shows that state ownership lowers the hazard of large firms switching, but no similar effect is found in SMEs. These implies that the switch behaviour of SMEs are not determined by their ownership structure, whether they have a CEO change or relationships with non-SOBs. Interestingly, the coefficient on the Opaqueness (or degree of transparency) variable is statistically positive and significant in the non-SOEs and SMEs groups, implying that the opacity associated with non-SOEs or SMEs, increases the hazard of switching ${ }^{23}$, which contradicts the expectation that less transparent firms are more likely to stay with their incumbent relationship because it might be difficult for them to access loan from 'outside' bank ${ }^{24}$.

\footnotetext{
${ }^{23}$ This could be a bank 'push' effect than a firm 'switch' effect in that the bank may encourage the firm to look elsewhere for the renewal of a loan.

${ }^{24}$ This variation could be possibly due to our sample are from publicly listed companies.
} 
Table 2: Estimated results of Cox proportional hazard model (coefficients)

\begin{tabular}{|c|c|c|c|c|c|c|}
\hline Variable & $\begin{array}{c}(1) \\
\text { Benchmark }\end{array}$ & $\begin{array}{c}(2) \\
\text { nonSOBs } \\
\end{array}$ & $\begin{array}{c}(3) \\
\text { SOEs }\end{array}$ & $\begin{array}{c}\text { (4) } \\
\text { non-SOEs }\end{array}$ & $\begin{array}{c}(5) \\
\text { Large }\end{array}$ & $\begin{array}{c}(6) \\
\text { SMEs }\end{array}$ \\
\hline \multicolumn{7}{|l|}{ Firm } \\
\hline Age & $-0.001 * *$ & -0.000 & -0.000 & -0.000 & $-0.001 * *$ & -0.000 \\
\hline Size & $-0.072 * * *$ & $-0.074 * * *$ & $-0.067 * *$ & $-0.074 * * *$ & & \\
\hline SOE & $-0.103 * * *$ & $-0.105 * * *$ & & & $-0.126 * *$ & -0.100 \\
\hline Profit & 0.004 & 0.004 & -0.003 & $0.008^{* *}$ & 0.003 & 0.004 \\
\hline Leverage & $-0.008 * * *$ & $-0.008 * * *$ & $-0.007 * *$ & $-0.011 * * *$ & $-0.012 * * *$ & $-0.006 * *$ \\
\hline Cash flows & -0.003 & -0.003 & -0.007 & -0.001 & -0.003 & -0.001 \\
\hline Growth & -0.000 & -0.000 & 0.007 & -0.000 & -0.001 & 0.001 \\
\hline Collateral & -0.000 & -0.000 & 0.000 & -0.000 & -0.000 & 0.000 \\
\hline Opaqueness & 0.001 & 0.001 & -0.002 & $0.005^{* *}$ & -0.001 & $0.004 * * *$ \\
\hline Industry & Yes & Yes & Yes & Yes & Yes & Yes \\
\hline \multicolumn{7}{|l|}{ Management } \\
\hline CEOage & 0.000 & -0.000 & -0.001 & -0.000 & 0.001 & -0.002 \\
\hline Gender & -0.036 & -0.040 & -0.044 & -0.022 & -0.067 & -0.053 \\
\hline Tenure & $0.001 * * *$ & $0.001 * *$ & 0.001 & $0.001 * * *$ & $0.002 * * *$ & -0.000 \\
\hline Change & $0.225 * * *$ & $0.221 * * *$ & $0.174 * *$ & $0.265^{* * *}$ & $0.337 * * *$ & 0.041 \\
\hline \multicolumn{7}{|l|}{ Bank } \\
\hline SOB & $-0.398 * * *$ & & $-0.361 * * *$ & $-0.439 * * *$ & $-0.398 * * *$ & $-0.320 * * *$ \\
\hline JSCB & 0.026 & & 0.103 & -0.039 & 0.018 & 0.125 \\
\hline $\mathrm{CCB}$ & $0.156^{* * *}$ & & $0.157^{* *}$ & $0.147^{* *}$ & $0.201 * *$ & 0.155 \\
\hline nonSOB & & $0.460 * * *$ & & & & \\
\hline \multicolumn{7}{|l|}{ Environment } \\
\hline Lending rate & $0.080 * * *$ & $0.079 * * *$ & 0.051 & $0.115^{* * *}$ & $0.091 * * *$ & $0.112^{* *}$ \\
\hline Reserve & $0.016 * *$ & $0.016 * *$ & 0.012 & 0.017 & 0.015 & 0.004 \\
\hline Guidance & 0.010 & 0.009 & 0.008 & 0.015 & 0.005 & 0.023 \\
\hline Crisis & $-0.396 * * *$ & $-0.394 * * *$ & $-0.324 * * *$ & $-0.465 * * *$ & $-0.379 * * *$ & $-0.365 * *$ \\
\hline Change*SOB & $0.243 * * *$ & & $0.214 * *$ & 0.094 & 0.148 & 0.111 \\
\hline Obs. & 7,570 & 7,570 & 3,140 & 4,430 & 5,150 & 2,420 \\
\hline Mean duration & 27.38 & 27.38 & 30.97 & 23.55 & 28.33 & 25.33 \\
\hline
\end{tabular}

Note: $* * * * *, *$ denote significance level at $1 \%, 5 \%$, and $10 \%$ level, respectively. Column (1) presents the results of the benchmark model using semiparametric Cox model; Column (2) re-estimate the benchmark model while uses a new variable 'nonSOB' to denote the ownership of lending banks which includes all types of banks except the five large SOBs (Big5); Columns (3) and (4) present separate results for the group of 'state-owned' firms and 'non-state owned' firms, respectively; Columns (5) and (6) shows separate results for the group of 'large' firms and 'SMEs' firms. The results of adding different sets of regressors have been displayed in Table 3. 


\subsection{Robustness test}

To check the robustness of the estimated results in Table 3, we control for regional effects and the number of bank relationship and use the Cox proportional hazard model to analyse the effects of these covariates. We allow for the possibility that economic development policy, and financial environment varies across cities and provinces in China by controlling for a locational effect on firm-bank relationship and firms switching behaviour. According to the geographical location of firms, this study uses four city dummies to examine whether firms located in the most developed first-tier cities in China are more likely to switch lenders, as they are assumed to be granted loans more easily in these areas.

As Elsas (2005) suggests, exclusivity gives rise to a lower degree of direct competition between banks, which allows for unique access to valuable information and eases the realization of the economic benefits associated with relationship lending, for example, efficient renegotiation of loan contract. It is argued that there is a negative correlation between the number of banks in a multiple bank relationship and the incidence of relationship lending or repeated lending. Hence, a variable Number has been employed to measure the number of bank relationship to examine its effect on Chinese firms' switch behaviour.

The results of robustness test are shown in Table $3^{25}$. Column (1) replicates the results of benchmark model from Table 3-Column (1). Column (2) shows the results of robustness check by adding the variable 'Number' and four city dummies, they are 'Beijing', 'Shanghai', 'Guangzhou' and 'Shenzhen'. Columns (3) to (8) show the estimated coefficients for adding additional set of covariates. As can be seen from this table, our main results are maintained. Firms that have multiple bank relationships are more likely to switch, the more relationship they have, the higher the likelihood of switching. It is not hard to understand because more bank relationships imply a firm is less loyal to its main bank, thus the likelihood to have multiple bank relationships or switch lender is higher. In addition, firms located in Shanghai has lower hazard of switching, this could be interpreted as firms located in the financial centre of China enjoy more stable bank relationships and they are less likely to suffer financial difficulty because their credit needs can always be fulfilled by their current credit provider. Shanghai has a relatively complete and mature financial market system, firms enjoy higher

\footnotetext{
${ }^{25}$ In addition to the semiparametric analysis, we also estimated the hazard function by parametric methods. The results using both Weibull and Exponential specification are almost in line with the results from using semiparametric analysis - Cox proportional hazard model. The results are available on request.
} 
liquidity and better financial condition and support from financial institutions in the financial centre of China. Although the signs of other three regional dummies are positive these effects are insignificant. Overall, the results of adding and dropping different regressors are almost in line with the results from benchmark model for some covariates, but some of the coefficients vary slightly. For example, adding additional regressors increases the effect of firm size and CEO change, while reduces the effect of state ownership and leverage. Nevertheless, using these four city dummies indicates the limitation of this robustness test because the number of firms from these four first-tier cities only accounts for one third of the sample. Hence, the regional effects are tenuous. 
Table 3: Estimated results of Cox proportional hazard model (coefficients)

\begin{tabular}{|c|c|c|c|c|c|c|c|c|}
\hline \multirow[t]{2}{*}{ Variable } & \multirow{2}{*}{\multicolumn{2}{|c|}{$\begin{array}{c}(1) \\
\text { Benchmark } \\
\end{array}$}} & \multirow{2}{*}{\multicolumn{2}{|c|}{ (4) }} & \multirow{2}{*}{\multicolumn{2}{|c|}{ (6) }} & \multirow{2}{*}{\multicolumn{2}{|c|}{ (8) }} \\
\hline & & & & & & & & \\
\hline \multicolumn{9}{|l|}{ Firm } \\
\hline Age & $-0.001 * *$ & -0.000 & 0.000 & 0.000 & 0.000 & 0.000 & -0.000 & -0.000 \\
\hline Size & $-0.072 * * *$ & $-0.078 * * *$ & $-0.054 * * *$ & $-0.064 * * *$ & $-0.061 * * *$ & $-0.075 * * *$ & $-0.069 * * *$ & $-0.077 * * *$ \\
\hline SOE & $-0.103 * * *$ & $-0.097 * *$ & $-0.167 * * *$ & $-0.164 * * *$ & $-0.146 * * *$ & $-0.139 * * *$ & $-0.122 * * *$ & $-0.115 * * *$ \\
\hline Profit & 0.004 & 0.005 & 0.001 & 0.001 & 0.003 & 0.003 & 0.003 & 0.004 \\
\hline Leverage & $-0.008 * * *$ & $-0.008 * * *$ & $-0.011 * * *$ & $-0.011 * * *$ & $-0.009 * * *$ & $-0.009 * * *$ & $-0.009 * * *$ & $-0.009 * * *$ \\
\hline Cash flows & -0.003 & -0.003 & $-0.006 * * *$ & $-0.006 * * *$ & $-0.005^{* *}$ & $-0.005 * *$ & $-0.006^{* * *}$ & $-0.006 * * *$ \\
\hline Growth & -0.000 & -0.000 & -0.000 & -0.000 & -0.000 & -0.000 & -0.000 & -0.000 \\
\hline Collateral & -0.000 & -0.000 & 0.000 & 0.000 & -0.000 & -0.000 & -0.000 & -0.000 \\
\hline Opaqueness & 0.001 & 0.001 & 0.001 & 0.001 & 0.001 & 0.001 & 0.001 & 0.002 \\
\hline Industry $^{26}$ & Yes & Yes & Yes & Yes & Yes & Yes & Yes & Yes \\
\hline \multicolumn{9}{|l|}{ Management } \\
\hline CEOage & 0.000 & 0.000 & & & 0.001 & 0.001 & 0.001 & 0.001 \\
\hline Gender & -0.036 & -0.060 & & & 0.015 & -0.011 & -0.013 & -0.036 \\
\hline Tenure & $0.001 * *$ & $0.001 *$ & & & $0.002 * * *$ & $0.002 * * *$ & $0.002 * * *$ & $0.002 * * *$ \\
\hline Change & $0.225 * * *$ & $0.200 * * *$ & & & $0.218 * * *$ & $0.240 * * *$ & $0.232^{* * * *}$ & $0.245^{* * *}$ \\
\hline \multicolumn{9}{|l|}{ Bank } \\
\hline SOB & $-0.398 * * *$ & $-0.399 * * *$ & & & & & $-0.431 * * *$ & $-0.433 * * *$ \\
\hline JSCB & 0.026 & 0.016 & & & & & 0.005 & -0.006 \\
\hline $\mathrm{CCB}$ & $0.156^{* * *}$ & $0.141 * * *$ & & & & & $0.142 * * *$ & $0.126^{* *}$ \\
\hline \multicolumn{9}{|l|}{ Environment } \\
\hline Lending rate & $0.080 * *$ & $0.085 * *$ & & & & & & \\
\hline Reserve & $0.016 *$ & $0.015 *$ & & & & & & \\
\hline Guidance & 0.010 & & & & & & & \\
\hline Crisis & $-0.396 * * *$ & $-0.397 * * *$ & & & & & & \\
\hline Change*SOB & $0.243 * * *$ & & & & & & & \\
\hline \multicolumn{9}{|l|}{ Other } \\
\hline Number & & $0.023 * * *$ & & $0.027 * * *$ & & $0.025 * * *$ & & $0.025 * * *$ \\
\hline Beijing & & 0.091 & & $0.101^{*}$ & & $0.144^{* *}$ & & 0.075 \\
\hline Shanghai & & $-0.305 * * *$ & & $-0.195 * *$ & & $-0.313 * * *$ & & $-0.300 * * *$ \\
\hline Guangzhou & & 0.112 & & 0.165 & & 0.170 & & 0.147 \\
\hline Shenzhen & & 0.029 & & 0.014 & & 0.023 & & 0.004 \\
\hline Obs. & 7,570 & 7,570 & 9,753 & 9,753 & 7,570 & 7,570 & 7,570 & 7,570 \\
\hline
\end{tabular}

Note: $* * *, * *, *$ denote significance level at $1 \%, 5 \%$, and $10 \%$ level, respectively. Column (1) replicates the results of benchmark model from Table 2; Column (2) shows the results of robustness check by adding the number of bank relationships and regional dummies (Beijing, Shanghai, Guangzhou and Shenzhen); Columns (3) to (8) present the results of adding different sets of variables (firms' characteristics, managerial characteristics, bank characteristics, crisis dummy and interaction terms) additionally. More specifically, Columns (3), (5) and (7) presents the results prior to the robustness test, while Columns (4), (6) and (8) are performed to check the robustness by including the number of bank relationship and locational dummies.

\footnotetext{
${ }^{26}$ We do not report the coefficients of eight sector dummies to save space, the full estimation results are available on request.
} 


\section{Conclusion}

What causes firms to change to different loan provider in China? Using 7,570 effective firmbank loan relationships matched data during 1996-2016, this paper has used survival analysis to investigate the causes of the changes to firm-bank relationship and the hazard of a firm changing its bank loan provider which we define as a 'switch'. A switch is defined as a firm borrows from a bank that it did not have a loan relationship in the prior 12 months. The estimated results provide evidence that the main drivers of firms' switching behaviour are a mixture of their credit needs, the attributes of firms and bank ownership-type, as well as the macro-economic environmental factor.

Controlling for time-varying and time-invariant covariates of firm's characteristics, management characteristics, bank type-ownership and the economic environment, this study finds small and young firms, less leveraged firms and firms with multiple bank relationships are more likely to switch to other banks, which shares some common findings with Ongena and Smith (2001), Farinha and Santos (2002), Gopalan, Udell and Yerramilli (2011), and Bouchellal and Castro (2016). Controlling for industry, firms operating in the real estate sector have a relatively higher hazard of switch banks, compared to other sectors. In addition, this study shows that the characteristic of executives has significant positive effects on the hazard of firms switching. The hazard of firms switching will be higher if they experience a change to the CEO during the relationship period, and their tenure will increase the likelihood of changing banks. Although changing CEO may increase the tendency to switch for four groups of enterprises, the impact of changing CEO on the hazard of switching is greater for non-SOEs and large groups enterprises, compared to SOEs or SMEs.

Firms that borrow from non-SOBs have a higher hazard of changing their bank loan provider (switching), while firms that have a loan relationship with the five large-scaled state commercial banks (SOBs) are more likely to stay longer in a stable bank relationship and less likely to change loan providers. Increasing the PBoC's benchmark lending rate and reserve requirement ratio during the tight monetary policy period may push firms to switch, this may be due to an increase in bargaining power from the lending side. Likewise, all firms are less likely to switch in times of economic crisis as in the 2008-2009 period. SOBs and SOEs have super stable firm-bank relationships, as for the rest; small, young and non-SOEs, firms with lower leverage, and multiple bank relationships, and operating in the real estate sector are more likely to switch. Firms that borrow from non-SOBs are also more likely to switch. Significantly, 
a long CEO tenure and a CEO switch during the lending relationship increases the likelihood of a switch.

What do these results tell us about the Chinese banking system and the lending relationship with the company sector? It tells us that even in an environment of increasing commercialisation, an environment fostered by the continuous reforms to the banking sector, the firm-bank relationship between SOEs and SOBs remain strong, but the credit needs of the firm puts a strain on it. A change in the CEO increases the likelihood of a firm changing its loan provider but a change to whom? It is possible that in the case of the SOE-SOB relationship the change is to another SOB through the political connection route. While we do not have direct evidence of 'guanxi' type behaviour, we argue that our results can be interpreted as indirect evidence of its existence. In that sense, another interpretation is that the increased commercialisation of relationships in recent times has pushed firms away from the traditional 'guanxi' type of relationship in business, but these relationships particularly in the state-sector remain strong. Nearly half of firms maintain a multiple bank relationship and changing their loan provider does not cut them off from resurrecting a past bank relationship in the future. This paper addresses the drivers of the hazard of change in loan provider but the change to which bank, can be revealed in an analysis of a general matrix of behaviour typified by 'brand switching'. A cursory analysis suggests that SOEs tend to switch internally between SOBs (or Big5) only indicating the strength of relationship within state-owned businesses. But this is a subject of future research. 


\section{References}

Agostino, M., Gagliardi, F., Trivieri F., 2012. Bank competition, lending relationships and firm default risk: an investigation of Italian SMEs. International Small Business Journal, 30(8), 907 943.

Aka, B.E., 2006. On the duration of the financial system stability under liberalization. Emerging Markets Review, 7(2), 147-161.

Berger, A.N., Miller, N.H., Petersen, M.A., Rajan, R.G., Stein, J.C., 2005. Does function follow organizational form? Evidence from the lending practices of large and small banks. Journal of Finance, 76(2), 237-269.

Berger, A.N., Udell, G.F., 1995. Relationship lending and lines of credit in small firm finance. Journal of Business, 68(3), 351-381.

Boot, A., 2000. Relationship lending: what do we know? Journal of Financial Intermediation, 9(1), 7-25.

Boot, A., Thakor, A.V., 1994. Moral hazard and secured lending in an infinitely repeated credit market game. Intermediation Economic Review, 35(4), 899-920.

Boot, A., Thakor, A.V., 2000. Can relationship banking survive competition? Journal of Finance, 55(2), 679-713.

Bouchellal, A., Castro, V., 2016. On the length of bank-firm relationships: an empirical application to a major French bank. NIPE Working Paper. No. 01.

Caliendo, M., Künn, S., Uhlendorff, A., 2016. Earnings exemptions for unemployed workers: The relationship between marginal employment, unemployment duration and job quality, Labour Economics, 42, 177-193.

Charumilind, C., Kali, R., Wiwattanakantang, Y., 2006. Connected lending: Thailand before the financial crisis. Journal of Business, 79(1), 181-218.

Chen, H., Funke, M., Lozev, I., Tsang, A., 2017. To guide or not to guide? Quantitative monetary policy tool and macroeconomic dynamics in China. HKIMR Working Paper. No.09.

Claessens, S., Feijen, E., and Laeven, L., 2008. Political connections and preferential access to finance: The role of campaign contributions. Journal of Financial Economics, 88(3), 554580 .

Cole, R.A., 1998. The importance of relationships to the availability of credit. Journal of Banking and Finance, 22(6-8), 959-977.

Diamond, D., 1984. Financial intermediation and delegated monitoring. Review of Economic Studies. 51(3), 393-414.

Elsas, R., 2005. Empirical determinants of relationship lending. Journal of Financial Intermediation, 14(1), 32-57.

Elsas, R., Heinemann, F., Tyrell, M., 2004. Multiple but asymmetric bank financing: the case of relationship lending. CESifo Working Paper. No. 1251.

Elsas, R., Krahnen, J., 1998. Is relationship lending special? Evidence from credit-file data in Germany. Journal of Banking and Finance, 22(10-11), 1283-1316. 
Faccio, M., Maarchica, M.T., Mura, R., 2016. CEO gender, corporate risk-taking, and the efficiency of capital allocation. Journal of Corporate Finance, 39, 193-209.

Farinha, L.A., Santos, C.A.J., 2002. Switching from single to multiple banking relationships: determinants and implications. Journal of Financial Intermediation, 11(2), 124-151.

Gopalan, R., Udell, G.F., Yerramilli, V., 2011. Why do firms form new bank relationships? Journal of Financial and Quantitative Analysis, 46(5), 1-35.

Hadlock, C., James, C., 2002. Do banks provide financial slack? Journal of Finance, 57(3), 1383-1420.

He, R., 2010. An empirical study on firm-bank relationship and loan cost. Collected Essays On Finance and Economics, 1, 57-63. (in Chinese)

He, R., 2013. How do firm-bank relationship affect the collateral requirement of micro-smallmedium sized enterprises? Economic Management, 35, 53-61. (in Chinese)

Houston, J. F., Jiang, L., Lin, C., and Ma, Y., 2014. Political connections and the cost of bank loans. Journal of Accounting Research, 52(1), 193-243.

Hubert, F., Schafer, D., 2002. Coordination failure with multiple-source lending, the cost of protection against a powerful lender. Journal of Institutional and Theoretical Economics, 158(2), 256-275.

Ioannidou, V., Ongena, S., 2010. "Time for a change": Loan conditions and bank behaviour when firms switch banks. Journal of Finance, 65(5), 1847-1877.

Jenkins, S.P., 2004. "Survival Analysis," In. Colchester: Institute for Social and Economic Research, University of Essex.

Jimenez, G., Saurina, J., 2004. Collateral, type of lender and relationship banking as determinants of credit risk. Journal of Banking and Finance, 28(9), 2191-2212.

Khwaja. A., Mian. A., 2005. Do lenders favor politically connected firms? Rent provision in an emerging financial market. Quarterly Journal of Economics, 120(4), 1371-1411.

Klapper, L., Martinez-Peria, M., and Zia, B., 2015. Banking in the developing nations of Asia: Changes in ownership structure and lending over the financial crisis, in A Berger, P Molyneux, and J Wilson, The Oxford Handbook of Banking ( $2^{\text {nd }}$ Ed) Oxford: Oxford University Press.

Lee, L. W., Tang, Y., Yip, L., and Sharma, P., 2018. Managing customer relationships in the emerging markets - guanxi as a driver of Chinese customer loyalty. Journal of Business Research, 86(C), 356-365.

Luo, Z., Wang, Z., Liu, H., 2011. A theoretical and empirical study on the loan effect of the relationship between the bank and enterprises and the impact of the financial ecological environment, based on the perspective of China's growing SMEs. Chinese Review of Financial Studies, 2, 68-85. (In Chinese)

Matthews, K., Yin, W., 2019. Limited loan rate differentiation, guanxi, loan size and loan maturity in the Chinese bank credit market. Journal of the Asia Pacific Economy, 24(3), 381401.

Ongena, S., Smith, D.C., 2001. The duration of bank relationships. Journal of Financial Economics, 61(3), 449-475. 
Petersen, M.A., Rajan, R.G., 1995. The effect of credit market competition on lending relationships. Quarterly Journal of Economics, 110(2), 407-443.

Rajan, R.G., 1992. Insiders and outsiders: the choices between informed and aim's length debt, Journal of Finance, 47(7), 1367-1400.

Sakai, K., Uesugi, I., Watanabe, T., 2010. Firm age and the evolution of borrowing cost: evidence from Japanese small firms. Journal of Banking and Finance, 34(8), 1970-1981.

Sharpe, S., 1990. Asymmetric information, bank lending and implicit contracts: a stylized model of customer relationships. The Journal of Finance, 45(4), 1069-1087.

Stephan, A., Taspin, A., Talavera, O., 2012. Main bank power, switching costs, and firm performance: theory and evidence from Ukraine. Emerging Markets Finance and Trade, 48(2), 76-93.

Wen, Y., Wu, J., 2014. Withstanding great recession like China. Federal Reserve Bank of St. Louis Working Paper. No. 007C.

Wong, M., 2007. Guanxi and its role in business. Chinese Management Studies, 1(4), 257-276.

Wu, J., 2005. The pricing behaviour of SMEs' relational loans: an empirical study base on a county branch of a state-owned bank in Jiangsu province. Journal of Nanjing University, 6. (in Chinese)

Yang, Z., Fan, Y., Shi, S., Liao J., 2018. Political connections and corporate borrowing: an analysis on the listed real estate firms in China. Journal of Real Estate Finance and Economics, 57(3), 315-350.

Yin, W., Matthews, K., 2016. The determinants and profitability of switching costs in Chinese banking. Applied Economics, 48(3), 4156-4166.

Yin, W., Matthews, K., 2017. Bank lending and bank relationships in China: Guanxi or commercial? Managerial Finance, 43(4), 425-439.

Yin, X., 2017. CEO turnover, the uncertainty of accounting information and bank loan. Finance and Accounting Monthly, 2, 10-16. (in Chinese)

Yin, Z., Qian, L., Wu, Y., 2015. Bank-firm relationship, bank competition and cost of loan for SMEs. Journal of Financial Research, 1, 134-149. (in Chinese)

Yu, M., Pan, H., 2008. The relationship between politics, institutional environments and private enterprises' access to bank loans. Management World, 8, 65-77. (in Chinese)

Yu, R., Xu, Y., 2016. The influence of changing frequency of CEOs on the performance of Chinese private listed companies. Research on Economics and Management, 2, 132-137. (in Chinese)

Zhou, H., Li, H., 2005. Relational financing in small-medium sized enterprises: empirical evidence and theoretical explanation. Nankai Business Review, 1, 69-74. (in Chinese)

Zhou, P., Dixon, H., 2018. The Determinants of Price Rigidity in the UK: Analysis of the CPI and PPI Microdata and Application to Macrodata Modelling. The Manchester School, 1-38. 


\section{Appendix A}

\section{A.1 Commercialisation}

China's banking industry has undergone major transformational changes such as specialization, commercialization, and marketization since 1978. Specifically, state-owned banks have been commercialized and restructured into a more market-based footing since the early 1990s. Shareholding banks have been established and recognized since 1996, and markets have been gradually opened up to foreign-owned banks, and to Chinese-foreign joint-venture financial institutions since the early 2000s.

The banking system has at its core the Peoples' Bank of China (the central bank), with five large state-owned commercial banks as the mainstay, with competition among various types of banking financial institutions that include joint-stock commercial banks, city commercials banks, rural banks and other financial institutions. Compared with the pre-reform banking system that was dominated by the central bank and four specialized commercial banks, the market share of major types of banks change significantly, which can be seen from Figure 1A. In addition, Figure 2A indicates that the private sector's ability to access bank loans significantly increased starting in 2010, or even earlier. The new system of development has moved forward in the new period of development in a relatively more competitive and commercialised environment. 
Figure 1A: Markets shares of major groups of banks

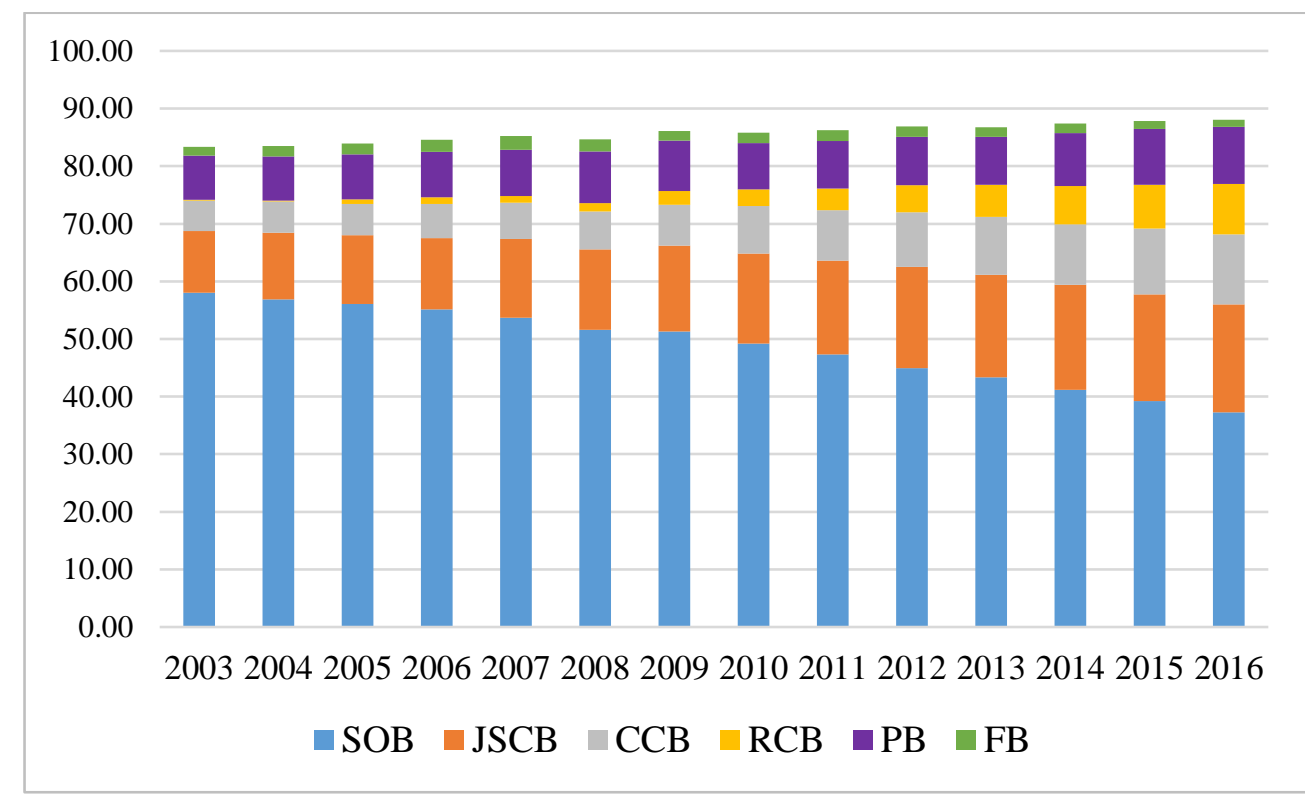

Note: $S O B$ indicates five largest State-owned commercial banks (Big5); JSCB indicates Joint-stock commercial banks; $C C B$ indicates City commercial banks; $R C B$ indicates Rural commercial banks; $P B$ indicates Policy banks; $F B$ indicates foreign banks.

Source: China Banking Regulatory Commission Annual Report (2017).

Figure2A: Flow of enterprise loans by ownership, 2010-12

(\% of total enterprise loan)

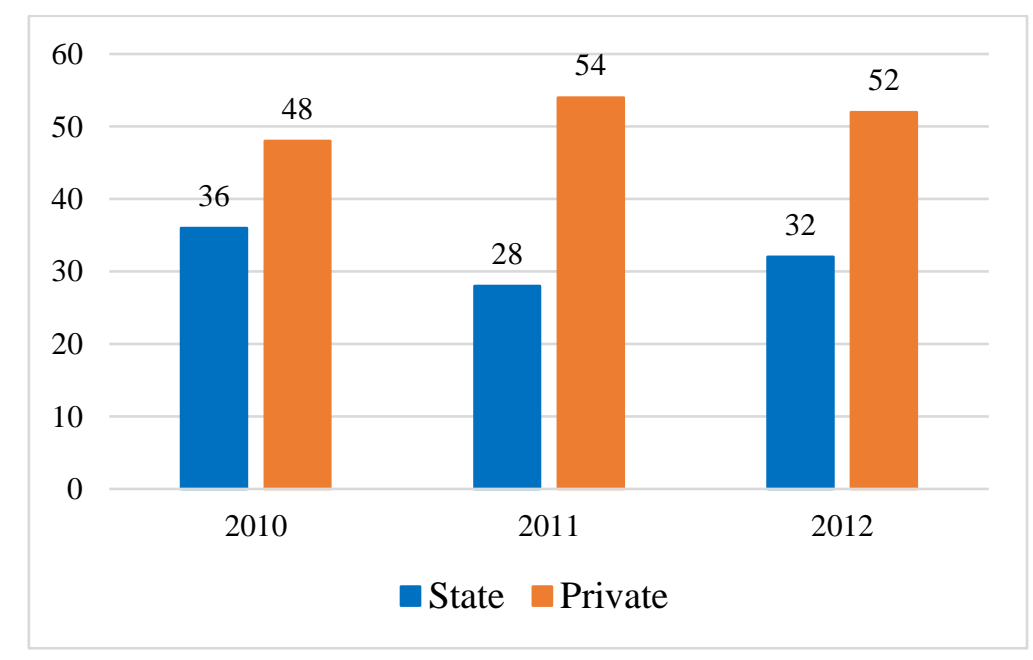

Sources: China Banking Association (2011, 2012, 2013).

\section{A.2 Variable Descriptions}


Table 1A: Description of the variables, and expected signs

\begin{tabular}{|c|c|c|c|}
\hline Variables & Description & Unit & Sign \\
\hline Duration & Duration of a firm-bank relationship lasts. & Month & \\
\hline Age & Age of the firm when the firm switches. & Month & $+/-$ \\
\hline Size & $\begin{array}{l}\text { Natural logarithm of year-ended total asset deflated by } \\
\text { the Chinese GDP deflator. }\end{array}$ & CNY & + \\
\hline$S O E$ & $\begin{array}{l}\text { Dummy variable that takes value } 1 \text { when the firm is } \\
\text { state-owned enterprise, } 0 \text { otherwise. }\end{array}$ & - & - \\
\hline Profit & Return on assets. & $\%$ & + \\
\hline Leverage & Percentage of long-term debt to total assets. & $\%$ & - \\
\hline Cash flows & Percentage of cash and cash equivalents to total assets. & $\%$ & - \\
\hline Growth & Percentage of sales growth. & $\%$ & - \\
\hline Collateral & Percentage of tangible assets to total debt. & $\%$ & + \\
\hline Opaqueness & Percentage of intangible assets to total assets. & $\%$ & - \\
\hline Industry & $\begin{array}{l}\text { Eight sector dummies that takes value } 1 \text { when the firm is } \\
\text { operating in the sector of Agriculture /Mining } \\
\text { /Manufacturing /Construction /Transportation /Energy } \\
\text { /Real estate /Service, } 0 \text { otherwise. }\end{array}$ & - & $+/-$ \\
\hline CEOage & Age of CEO when the firm switches. & Year & $+/-$ \\
\hline Gender & $\begin{array}{l}\text { Dummy variable that takes value } 1 \text { when the firm is run } \\
\text { by a male CEO, } 0 \text { otherwise. }\end{array}$ & - & + \\
\hline Tenure & Tenure of CEO when the firm switches. & Month & - \\
\hline Change & $\begin{array}{l}\text { Dummy variable takes value } 1 \text { if there is a change in } \\
\text { CEO in a current relationship, } 0 \text { otherwise. }\end{array}$ & & - \\
\hline$S O B$ & $\begin{array}{l}\text { Dummy variable that takes value } 1 \text { if the lending bank is } \\
\text { the five largest state-owned commercial banks (also } \\
\text { known as Big5), } 0 \text { otherwise. }\end{array}$ & - & $+/-$ \\
\hline$J S C B$ & $\begin{array}{l}\text { Dummy variable that takes value } 1 \text { if the lending bank is } \\
\text { joint-stock commercial bank, } 0 \text { otherwise. }\end{array}$ & - & $+/-$ \\
\hline$C C B$ & $\begin{array}{l}\text { Dummy variable that takes value } 1 \text { if the lending bank is } \\
\text { city commercial bank, } 0 \text { otherwise. }\end{array}$ & - & $+/-$ \\
\hline nonSOB & $\begin{array}{l}\text { Dummy variable that takes value } 1 \text { if the lending bank is } \\
\text { not the largest state commercial banks (Big5). }\end{array}$ & - & + \\
\hline Lending rate & PBoC's one-year benchmark lending rate. & $\%$ & + \\
\hline Reserve & PBoC's reserve requirement ratio. & $\%$ & + \\
\hline Guidance & $\begin{array}{l}\text { Five dummy variables represent five stances of window } \\
\text { guidance policy that take value }-2 \text { for strongly } \\
\text { discouraging period, }-1 \text { for weakly discouraging period, } \\
0 \text { for no explicit direction, } 1 \text { for weakly encouraging } \\
\text { period and } 2 \text { for strongly encouraging period. }\end{array}$ & $\%$ & + \\
\hline Crisis & $\begin{array}{l}\text { Dummy variable that takes value } 1 \text { if the year of } \\
\text { switching in crisis year } 2008 \text { and } 2009,0 \text { otherwise. }\end{array}$ & - & - \\
\hline $\begin{array}{l}\text { Change*Firm( } \\
\text { or Bank) }\end{array}$ & $\begin{array}{l}\text { Cross effect of CEO change dummy and different types } \\
\text { of firm or bank. }\end{array}$ & - & $+/-$ \\
\hline $\begin{array}{l}\text { Crisis*Firm(or } \\
\text { Bank }\end{array}$ & $\begin{array}{l}\text { Cross effect of crisis dummy and different types of firm } \\
\text { or bank }\end{array}$ & - & $+/-$ \\
\hline
\end{tabular}

Table 2A: Statistical definitions of large, small and medium sized firms 


\begin{tabular}{|c|c|c|c|c|c|}
\hline Industry category & Index & Unit & Large & Medium-sized & Small \\
\hline $\begin{array}{l}\text { Farming, forestry, } \\
\text { animal husbandry } \\
\text { and fishing }\end{array}$ & $\begin{array}{c}\text { Operating } \\
\text { income }(\mathrm{Y})\end{array}$ & 10,000 & $Y \geq 20000$ & $500 \leq Y<20000$ & $50 \leq \mathrm{Y}<500$ \\
\hline \multirow{2}{*}{ Industry } & Employees(X) & People & $X \geq 1000$ & $300 \leq X<1000$ & $20 \leq X<300$ \\
\hline & $\begin{array}{c}\text { Operating } \\
\text { income(Y) }\end{array}$ & 10,000 & $Y \geq 40000$ & $2000 \leq \mathrm{Y}<40000$ & $300 \leq Y<2000$ \\
\hline \multirow{2}{*}{ Construction } & $\begin{array}{c}\text { Operating } \\
\text { income }(Y)\end{array}$ & 10,000 & $Y \geq 80000$ & $6000 \leq Y<80000$ & $300 \leq \mathrm{Y}<6000$ \\
\hline & Total assets $(Z)$ & 10,000 & $\mathrm{Z} \geq 80000$ & $5000 \leq \mathrm{Z}<80000$ & $300 \leq \mathrm{Z}<5000$ \\
\hline \multirow{2}{*}{ Wholesale } & Employees $(\mathrm{X})$ & People & $X \geq 200$ & $20 \leq X<200$ & $5 \leq X<20$ \\
\hline & $\begin{array}{c}\text { Operating } \\
\text { income }(Y)\end{array}$ & 10,000 & $Y \geq 40000$ & $5000 \leq Y<40000$ & $1000 \leq Y<5000$ \\
\hline \multirow{2}{*}{ Retail } & Employees(X) & People & $X \geq 300$ & $50 \leq X<300$ & $10 \leq X<50$ \\
\hline & $\begin{array}{c}\text { Operating } \\
\text { income }(Y)\end{array}$ & 10,000 & $Y \geq 20000$ & $500 \leq Y<20000$ & $100 \leq Y<500$ \\
\hline \multirow{2}{*}{ Transport } & Employees(X) & People & $X \geq 1000$ & $300 \leq X<1000$ & $20 \leq X<300$ \\
\hline & $\begin{array}{c}\text { Operating } \\
\text { income }(Y)\end{array}$ & 10,000 & $Y \geq 30000$ & $3000 \leq Y<30000$ & $200 \leq \mathrm{Y}<3000$ \\
\hline \multirow{2}{*}{ Storage } & Employees(X) & People & $X \geq 200$ & $100 \leq X<200$ & $20 \leq X<100$ \\
\hline & $\begin{array}{c}\text { Operating } \\
\text { income }(\mathrm{Y})\end{array}$ & 10,000 & $Y \geq 30000$ & $1000 \leq Y<30000$ & $100 \leq \mathrm{Y}<1000$ \\
\hline \multirow{2}{*}{ Post } & Employees(X) & People & $X \geq 1000$ & $300 \leq X<1000$ & $20 \leq X<300$ \\
\hline & $\begin{array}{l}\text { Operating } \\
\text { income(Y) }\end{array}$ & 10,000 & $Y \geq 30000$ & $2000 \leq \mathrm{Y}<30000$ & $100 \leq \mathrm{Y}<2000$ \\
\hline \multirow{2}{*}{ Hotels } & Employees(X) & People & $X \geq 300$ & $100 \leq X<300$ & $10 \leq X<100$ \\
\hline & $\begin{array}{c}\text { Operating } \\
\text { income }(\mathrm{Y})\end{array}$ & 10,000 & $Y \geq 10000$ & $2000 \leq Y<10000$ & $100 \leq \mathrm{Y}<2000$ \\
\hline \multirow{2}{*}{ Catering service } & Employees(X) & People & $X \geq 300$ & $100 \leq X<300$ & $10 \leq X<100$ \\
\hline & $\begin{array}{l}\text { Operating } \\
\text { income(Y) }\end{array}$ & 10,000 & $Y \geq 10000$ & $2000 \leq \mathrm{Y}<10000$ & $100 \leq Y<2000$ \\
\hline \multirow{3}{*}{$\begin{array}{l}\text { Information } \\
\text { transmission }\end{array}$} & Employees(X) & People & $X \geq 2000$ & $100 \leq X<2000$ & $10 \leq X<100$ \\
\hline & $\begin{array}{l}\text { Operating } \\
\text { income(Y) }\end{array}$ & 10,000 & $Y \geq 100000$ & $1000 \leq Y<100000$ & $100 \leq Y<1000$ \\
\hline & Employees(X) & People & $X \geq 300$ & $100 \leq X<300$ & $10 \leq X<100$ \\
\hline
\end{tabular}




\begin{tabular}{|c|c|c|c|c|c|}
\hline $\begin{array}{c}\text { Software and } \\
\text { information } \\
\text { technology services }\end{array}$ & $\begin{array}{c}\text { Operating } \\
\text { income(Y) }\end{array}$ & 10,000 & $\mathrm{Y} \geq 10000$ & $1000 \leq \mathrm{Y}<10000$ & $50 \leq \mathrm{Y}<1000$ \\
\hline \multirow{2}{*}{ Real estate } & $\begin{array}{c}\text { Operating } \\
\text { income(Y) }\end{array}$ & 10,000 & $\mathrm{Y} \geq 200000$ & $1000 \leq \mathrm{Y}<200000$ & $100 \leq \mathrm{Y}<1000$ \\
\cline { 2 - 6 } & Total assets(Z) & 10,000 & $\mathrm{Z} \geq 10000$ & $5000 \leq \mathrm{Z}<10000$ & $2000 \leq \mathrm{Z}<5000$ \\
\hline \multirow{2}{*}{ Property management } & Employees(X) & People & $\mathrm{X} \geq 1000$ & $300 \leq \mathrm{X}<1000$ & $100 \leq \mathrm{X}<300$ \\
\cline { 2 - 6 } & Operating & 10,000 & $\mathrm{Y} \geq 5000$ & $1000 \leq \mathrm{Y}<5000$ & $500 \leq \mathrm{Y}<1000$ \\
\hline \multirow{2}{*}{$\begin{array}{c}\text { Leasing and business } \\
\text { services }\end{array}$} & Employees(X) & People & $\mathrm{X} \geq 300$ & $100 \leq \mathrm{X}<300$ & $10 \leq \mathrm{X}<100$ \\
\cline { 2 - 6 } & Total assets(Z) & 10,000 & $\mathrm{Z} \geq 120000$ & $8000 \leq \mathrm{Z}<120000$ & $100 \leq \mathrm{Z}<8000$ \\
\hline Unspecified industry & Employees(X) & People & $\mathrm{X} \geq 300$ & $100 \leq \mathrm{X}<300$ & $10 \leq \mathrm{X}<100$ \\
\hline
\end{tabular}

Source: National Bureau of Statistics of China (2011)

Table 3A: Window guidance policy stance

\begin{tabular}{|c|c|c|c|}
\hline Indicator & Stance & Period & Definition \\
\hline-2 & Strongly discouraging & $\begin{array}{l}\text { 2003Q1-2004Q4 } \\
\text { 2006Q2-2008Q2 } \\
\text { 2009Q2-2010Q1 }\end{array}$ & $\begin{array}{l}\text { CMPR explicitly discourage } \\
\text { growth of total credit. }\end{array}$ \\
\hline-1 & Weakly discouraging & $\begin{array}{l}\text { 2005Q1-2006Q1 } \\
\text { 2010Q1-2012Q2 }\end{array}$ & $\begin{array}{l}\text { CMPR points the target of } \\
\text { optimizing credit structure, } \\
\text { provides risk warning, and/or } \\
\text { mentions that banks should } \\
\text { control the pace of credit growth. }\end{array}$ \\
\hline 0 & No explicit direction & $\begin{array}{l}\text { 2001Q1-2002Q4 } \\
\text { 2012Q3-2014Q2 }\end{array}$ & $\begin{array}{l}\text { CMPR only mentions the target } \\
\text { of optimizing credit structure and } \\
\text { separately listing the sectors that } \\
\text { should be both discouraging and } \\
\text { encouraging or no explicit } \\
\text { direction of credit growth. }\end{array}$ \\
\hline 1 & Weakly encouraging & 2014Q3-Present & $\begin{array}{l}\text { CMPR only lists sectors that to be } \\
\text { encouraged for the target of } \\
\text { optimizing credit structure. }\end{array}$ \\
\hline 2 & Strongly encouraging & $\begin{array}{l}\text { 1998Q1-2000Q4 } \\
\text { 2008Q3-2009Q1 }\end{array}$ & $\begin{array}{l}\text { CMPR explicitly encourages the } \\
\text { growth of total credit. }\end{array}$ \\
\hline
\end{tabular}

Source: Quarterly China Monetary Policy Report, and Chen et al. (2017). 


\section{A.3 Descriptive Analysis}

Finally, there is 18,233 matched firm-bank relationships includes 2,102 listed companies in our sample, $69 \%$ of these loan relationships with large firms, $31 \%$ with small and medium firms, and $44 \%$ with state-owned firms while $56 \%$ with non-state-owned firms. This complete matched dataset includes 1,326 large firms and 776 medium and small sized firms, more than half of the sample listed firms come from private sector or controlled by foreign firms. The distribution of loans among different groups and summary of sample listed firms by ownership and size have been shown in Figure 3A and Figure 4A, respectively.

\section{Figure 3A: Distribution of loans among different groups}
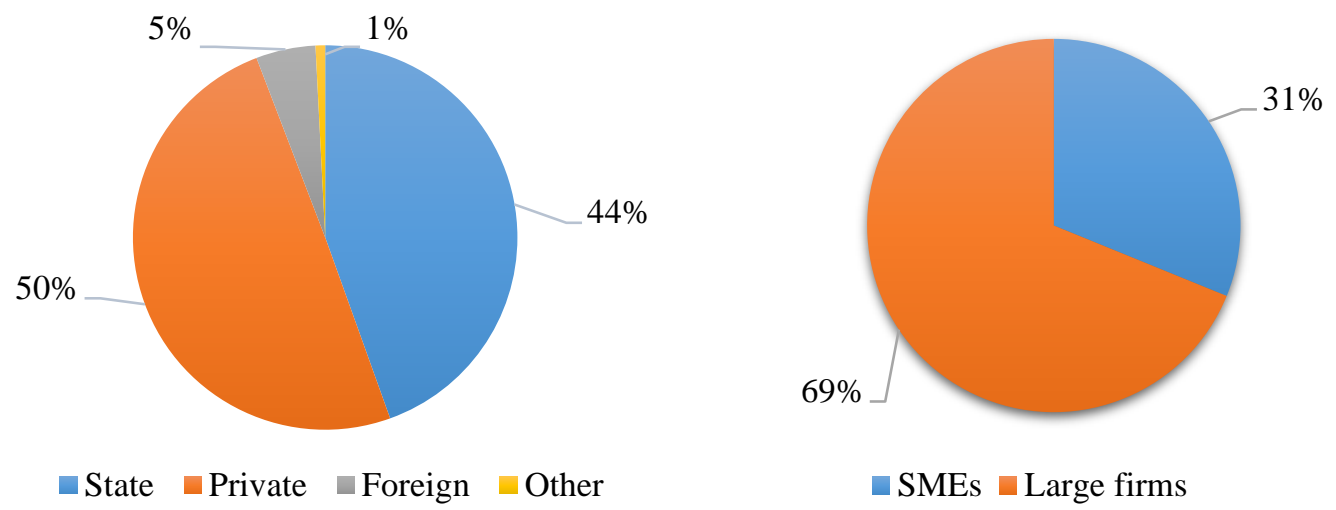

Figure 4A: Number of firms

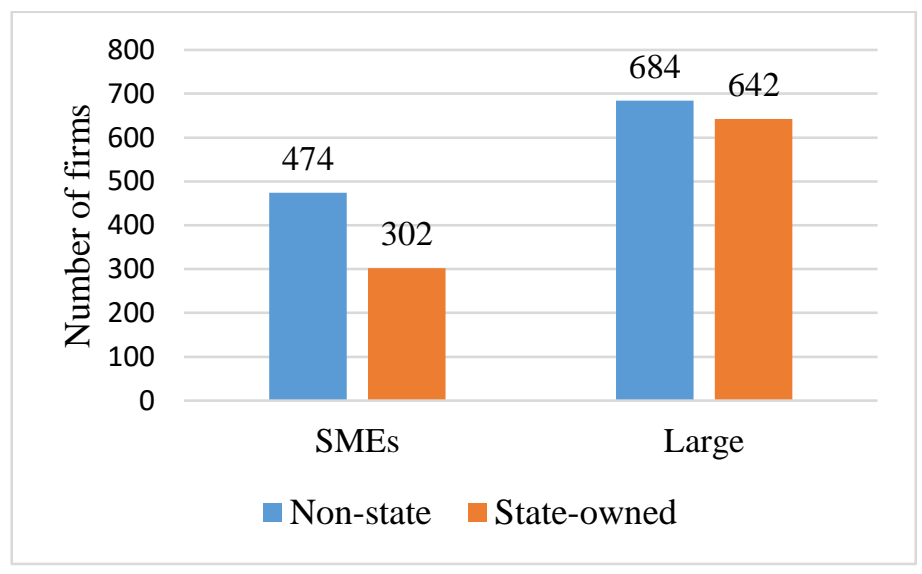

In addition, more than half of the sample listed firms running in manufacturing sector that accounts for $59 \%$ of these firm-bank relationships. The second and third largest groups of sectors are the service and real estate sector, which account for $16 \%$ and $7 \%$ of these relationships, respectively. Despite the largest three groups of sectors, the number of firms that running in other sectors such as mining, energy, transport, construction and agriculture have 
been summarized in Figure 5A. Moreover, lending banks measured by ownership has been displayed in Figure 6A, borrowing from the five large state-owned commercial banks (SOB or Big5) or joint-stock commercial banks (JSCB) account for one third of these borrowing lending relationships, the third largest type of lending bank is city commercial banks (CCB) with $16.94 \%$ lending relationships. Due to the borrowing relationships with foreign banks, policy banks and other financial institutions account for quite small proportions, we only include the largest three types of Chinese banks in the benchmark model of survival analysis.

Figure 5A: Number of firms in different sectors

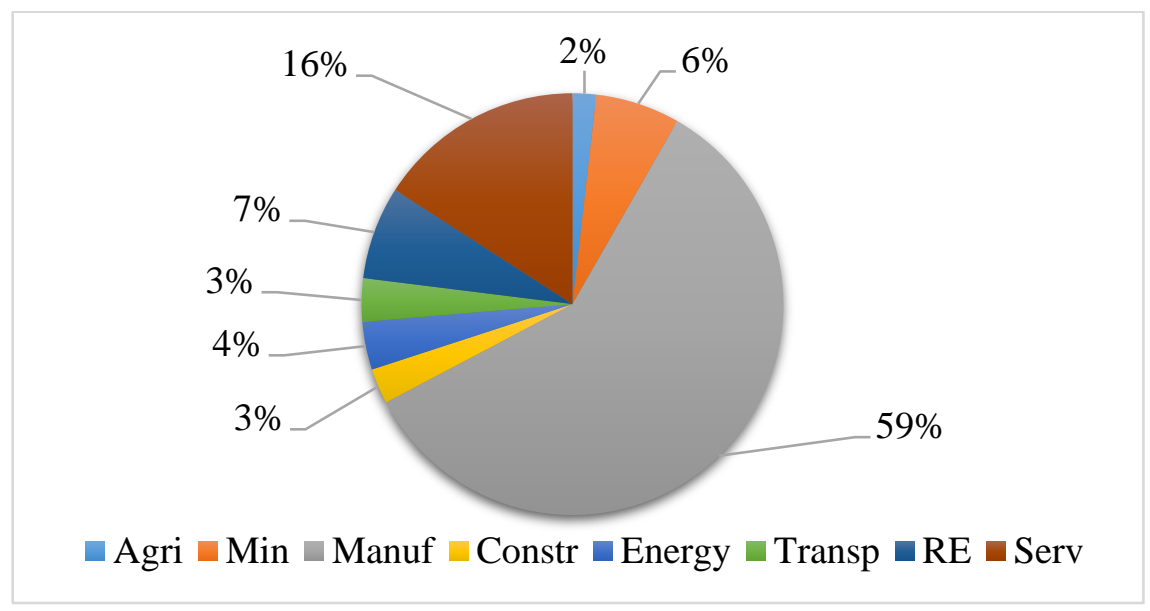

Note: Agri denotes Agriculture sector; Min indicates Mining sector; Manuf denotes Manufacturing sector; Constr denotes Construction sector; Energy denotes Energy sector; Transp denotes Transportation sector; $R E$ denotes Real Estate sector; Serv denotes Service sector.

Figure 6A: Number of lending banks

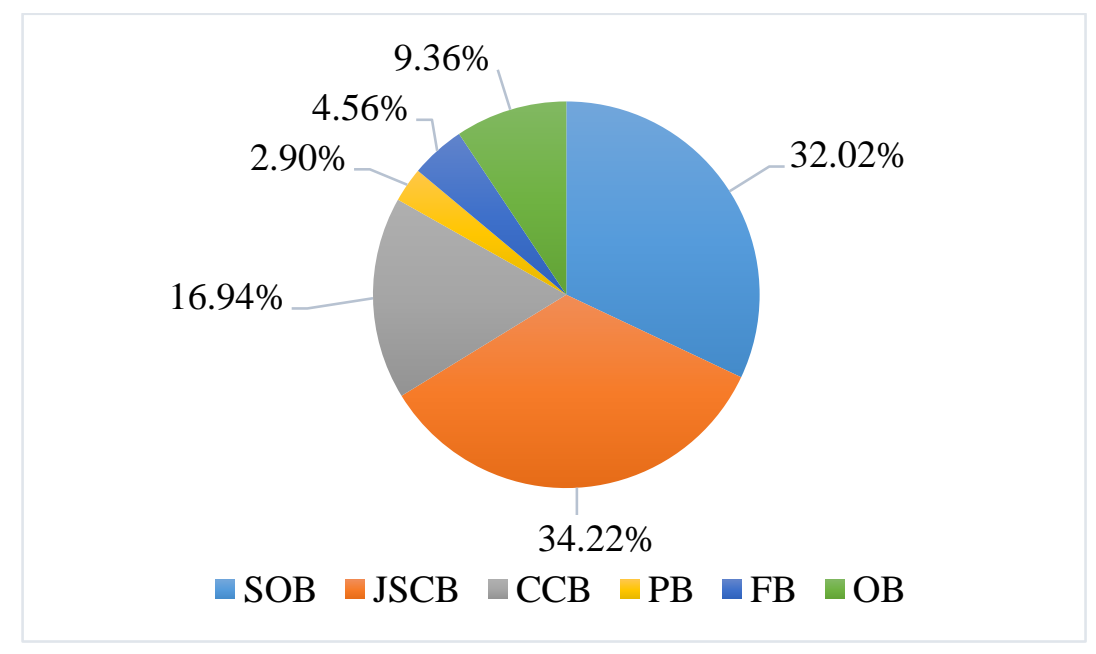

Note: $S O B$ denotes five large State-owned Commercial Banks (also known as the "Big5); JSCB denotes Joint-stock Commercial Banks; $C C B$ denotes City Commercial Banks, $P B$ denotes Policy Banks; $F B$ denotes Foreign Banks; $O B$ denotes other banks includes Rural Commercial Banks, Rural Cooperative Banks, Rural Credit Cooperatives, and other financial institutions. 


\section{Appendix B}

\section{B.1 Conceptual Framework}

\section{Figure 1B: Conceptual Framework}

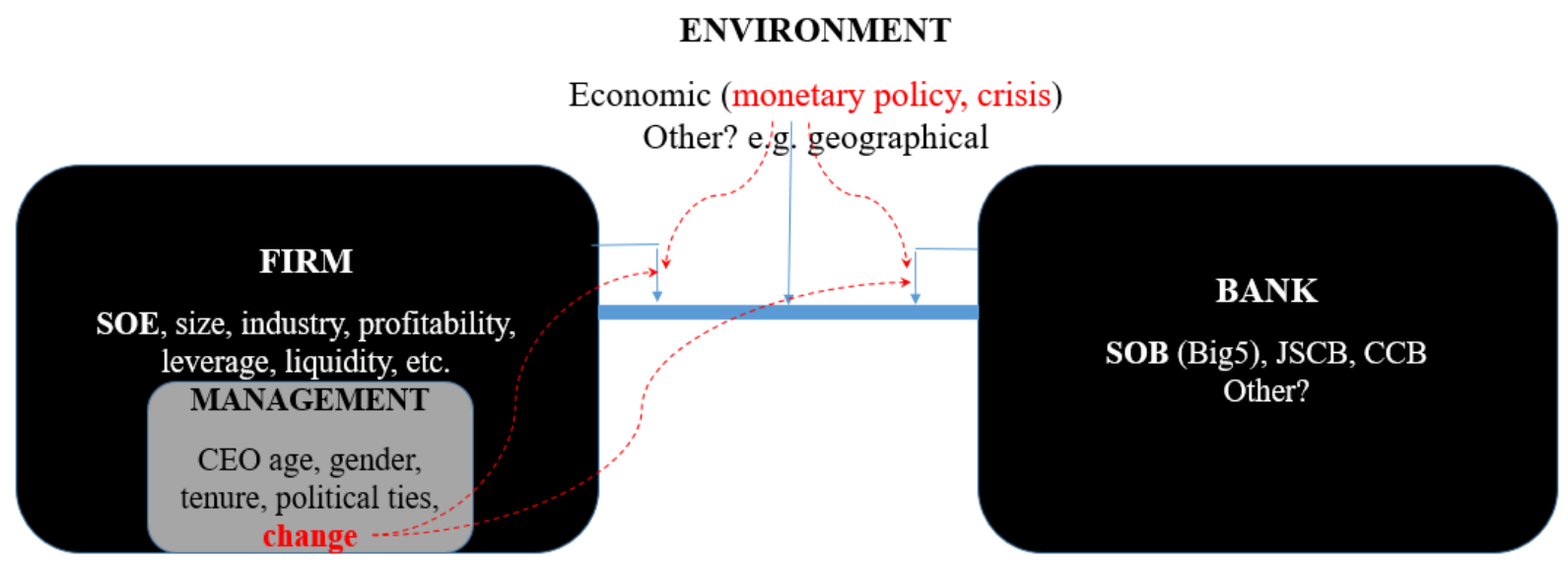

Note: There are two sides of the loan market which including the demand side by firm and supply side by bank. For the demand side, this study considers the firm's attributes such as ownership, size, industry, performance measures indicators (such as profitability, liquidity and leverage) and management characteristics, which includes executives' age, gender, tenure, and whether there is a CEO change in a firm-bank relationship. On the other side, due to the limit availability of the financial data for some small banks or bank's sub-branch in less developed regions, for the supply side, this study only considers the ownership structure of banks. Moreover, this study considers the environmental factors such as monetary policy condition and financial crisis period, as well as the regional effects in the robustness test.

\section{B.2 Matched firm-loan-bank data}

To perform a survival analysis, the data must be converted into duration format that includes the start and end date of a relationship duration. Using MATLAB program, we deal with the raw data and match the loan data (borrowing-lending records) with the corresponding firm's specific characteristics. The loan data shows that the bank loans could be obtained either from a single or multiple lenders. In addition, this loan data consists the information of the stock code of sample listed firms, name of lending banks, lending deals, and starting and ending date of loan relation. However, the information on this time span of lending relationship is not complete, as well as other deal indicators. For example, some of the observations have one missing loan indicator, but some of the observations have two or more missing loan indicators. Besides, some observations have missing starting or ending date of loan relationship or even 
both of this duration information. From these loan data, the announcement date (date of loan announcement listed company released on the publication specified by the stock exchange) is about two to ten days prior to the start date of loan borrowing. For those observations with nonavailable ending date of loan, these could be calculated by using the starting date plus the loan period. Secondly, the data for firm's specific characteristics and other variables such as deflator and exchange rates collected from the CSMAR database and World-Bank across the sample period from 1996 to 2016 has been matched to the loan data though MATLAB program. Concatenating the firm's identity (stock code) and the starting year of loan borrowing, the corresponding firm's characteristics, management characteristics, and environment factors in a specific year for a specific sample listed firm have been matched to firm's loan data at the start of loan relationship. One thing should be pointed out here is that the firm's switching behaviour cannot be identified without the information of lending bank, therefore this study excludes those observations that without information of lending banks, firms operated in financial sector are excluded as well. As a firm-loan-bank relationship has been counted as one observation, a firm with multiple bank relationships enters as two or more observations. After combining those repeated borrowings from their incumbent banks within 12 months to the previous firmbank relationship durations, and cleaning out observations that provided only partial information, the overall sample size reduces. Finally, there is a panel matched dataset with 7,570 firm-bank relationships which including 2,102 Chinese listed firms.

\section{B.3 Censoring}

The termination of firm-bank relationship or firm's switch behaviour may have not yet occurred by the end of the observation period, or the relationship duration may also have lasted for a while before entering the observation. In these cases, there are incomplete observations over time. Censoring is defined as when the failure (switch in this case) occurs and the subject is not under observation, which is a partial ignorance about the duration and can be categorized into three types:

(i) Right Censoring: the subject participates in the study for a time, but it is not under observation when failure occurs.

(ii) Left Censoring: the failure occurs at some time before the subject entering the observation. 
(iii) Interval Censoring: rather than observing the exact time of failure, all one know is that failure occurs between two known time points - perhaps a short or long interval.

Not knowing when a firm-bank (or loan) relationship starts, or when it ends, or both, implies that we are unable to observe the true duration of the relationship for these observations. There is not necessary to adjust left censoring in our data because all these relationships start in or after 1996. However, without the adjustment of right censoring, the estimation of the proportional hazard models produces biased and inconsistent estimates of model parameters. Some relationships do not end within the sample period, or some firms' switch behaviour of changing loan provider do not occur by the end of our observation period, thus we adjust right censoring when we generate the duration of these firm and bank relationships. As Jenkins (2004) has provided a detailed statistical presentation for dealing with censoring in an intuitive graph below, the solid line is the relationship duration under observation, with a start (circle) and an end (cross), while the dashed part means censoring.

Figure 2B: Censoring

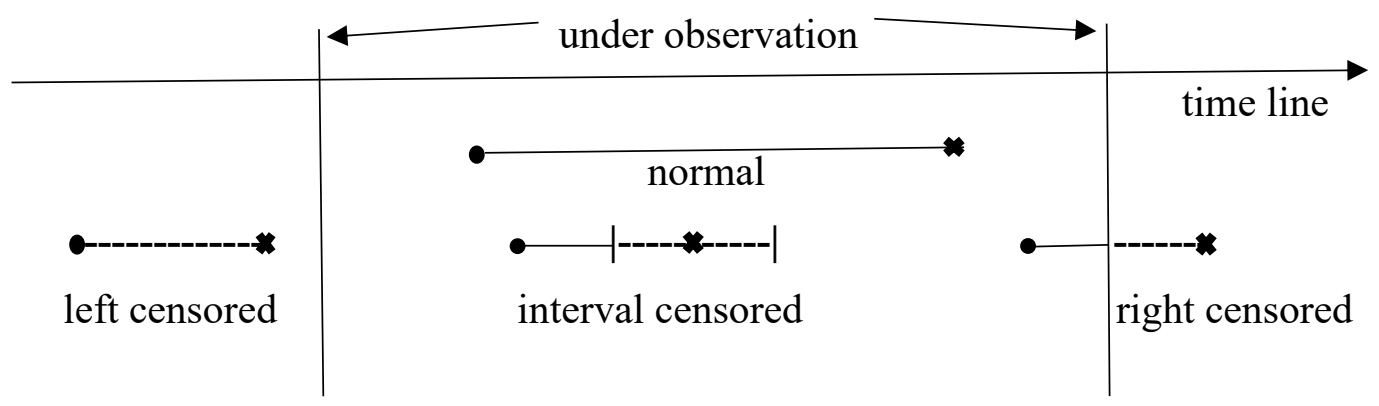




\section{Appendix C}

Table 1C: Additional Robustness Tests

\begin{tabular}{|c|c|c|c|c|}
\hline Variable & (1) & (2) & (3) & (4) \\
\hline \multicolumn{5}{|l|}{ Firm } \\
\hline Age & $-0.001 * *$ & 0.000 & $-0.001 * *$ & 0.000 \\
\hline Size & $-0.072 * * *$ & $-0.066^{* * *}$ & $-0.059 * *$ & $-0.080 * * *$ \\
\hline SOE & $-0.103 * * *$ & $-0.097 * * *$ & $-0.145^{* *}$ & $-0.114 * * *$ \\
\hline Profit & 0.004 & 0.003 & 0.006 & 0.002 \\
\hline Leverage & $-0.008 * * *$ & $-0.008 * * *$ & $-0.010 * * *$ & $-0.007 * * *$ \\
\hline Cash flows & -0.003 & -0.001 & $0.004 * *$ & -0.002 \\
\hline Growth & 0.000 & 0.000 & -0.001 & -0.001 \\
\hline Collateral & 0.000 & 0.0000 & $0.000 *$ & 0.000 \\
\hline Opaqueness & 0.001 & 0.000 & 0.000 & 0.003 \\
\hline Industry & Yes & Yes & Yes & Yes \\
\hline \multicolumn{5}{|l|}{ Management } \\
\hline CEOage & 0.000 & -0.001 & 0.002 & -0.001 \\
\hline Gender & -0.036 & -0.018 & -0.087 & -0.001 \\
\hline Tenure & $0.001 * * *$ & $0.001 * * *$ & $0.001 * * *$ & $0.002 * * *$ \\
\hline Change & $0.225 * * *$ & $0.197 * * *$ & $0.154 * * *$ & $0.251 * * *$ \\
\hline \multicolumn{5}{|l|}{ Bank } \\
\hline SOB & $-0.398 * * *$ & $-0.366^{* * *}$ & $-0.247 * * *$ & $-0.373^{*}$ \\
\hline JSCB & 0.026 & 0.003 & $0.138^{* *}$ & 0.283 \\
\hline $\mathrm{CCB}$ & $0.156 * * *$ & $0.131 * * *$ & $0.195 * * *$ & 0.075 \\
\hline \multicolumn{5}{|l|}{ Environment } \\
\hline Lending rate & $0.080 * * *$ & $0.107 * * *$ & $0.102 * * *$ & $0.110 * * *$ \\
\hline Reserve & $0.016 * *$ & $0.014 * *$ & $0.027 * * *$ & 0.009 \\
\hline Guidance & 0.010 & 0.009 & 0.023 & 0.004 \\
\hline Crisis & $-0.396^{* * *}$ & $-0.382 * * *$ & $-0.338 * * *$ & $-0.379 * * *$ \\
\hline $\begin{array}{l}\mathbf{i m r}^{27} \\
\text { (p-value) }\end{array}$ & & & & $\begin{array}{l}-9.166 \\
(0.586)\end{array}$ \\
\hline Obs. & 7,570 & 7,570 & 5,620 & 7,570 \\
\hline
\end{tabular}

Note: $* * *, * *, *$ denote significance level at $1 \%, 5 \%$, and $10 \%$ level, respectively. Column (1) replicates the results of benchmark model from Column (1) in Table 2; Columns (2)-(4) reports the results of additional robustness tests. Specifically, the model in Column (2) re-define the Type 2 switching that repeatedly borrow from same bank after a period that longer than 12 months gap as a non-switching behaviour (coded 'switch=0' for these observation) and re-estimate the benchmark model; Colum (3) excludes Type 2 switching and reestimate the benchmark model; Column (4) represents the result of Heckman Selection Two-steps Model.

\footnotetext{
27 ' $i m r$ ' indicates inverse mills ratio, which is an important parameter generated from the first stage of Heckman Selection Model. Some observations of some regressors are not available, which may result from the better observability of bigger companies. As suggested by an anonymous reviewer, we perform a selection bias test by using the two-steps Heckman Selection Model to check whether a selection bias problem presents in our model. However, the insignificant coefficient of the imr can confirm that there is no significant selection bias in our model, the data are therefore regarded as randomly selected by the model.
} 